\title{
Metformin potentiates the effects of paclitaxel in endometrial cancer cells through inhibition of cell proliferation and modulation of the mTOR pathway. 1
}

\author{
Rabbie K. Hanna ${ }^{2}$, Chunxiao Zhou ${ }^{2,3}$, Kimberly M. Malloy², Paola A Gehrig ${ }^{2,4}$, and Victoria \\ L. Bae-Jump $2,4,5$ \\ ${ }^{2}$ University of North Carolina, Department of Obstetrics and Gynecology, Division of Gynecologic \\ Oncology, Chapel Hill, NC
}

\begin{abstract}
Objectives-To examine the effects of combination therapy with metformin and paclitaxel in endometrial cancer cell lines.

Methods-ECC-1 and Ishikawa endometrial cancer cell lines were used. Cell proliferation was assessed after exposure to paclitaxel and metformin. Cell cycle progression was assessed by flow cytometry. hTERT expression was determined by real-time RT-PCR. Western immunoblotting was performed to determine the effect of metformin/paclitaxel on the mTOR pathway.
\end{abstract}

\begin{abstract}
Results-Paclitaxel inhibited proliferation in a dose-dependent manner in both cell lines with $\mathrm{IC}_{50}$ values of 1-5 $\mathrm{nM}$ and 5-10 $\mathrm{nM}$ for Ishikawa and ECC-1 cells, respectively. Simultaneous exposure of cells to various doses of paclitaxel in combination with metformin $(0.5 \mathrm{mM})$ resulted in a significant synergistic anti-proliferative effect in both cell lines (Combination Index <1).

Metformin induced G1 arrest in both cell lines. Paclitaxel alone or in combination with metformin resulted in predominantly G2 arrest. Metformin decreased hTERT mRNA expression while paclitaxel alone had no effect on telomerase activity. Metformin stimulated AMPK phosphorylation and decreased phosphorylation of the S6 protein. In contrast, paclitaxel inhibited AMPK phosphorylation in the ECC-1 cell line and induced phosphorylation of S6 in both cell lines. Treatment with metformin and paclitaxel resulted in decreased phosphorylation of S6 in both cell lines but only had an additive effect on AMPK phosphorylation in the ECC-1 cell line.
\end{abstract}

Conclusions-Metformin potentiates the effects of paclitaxel in endometrial cancer cells through inhibition of cell proliferation and modulation of the mTOR pathway. This combination may be a promising targeted therapy for endometrial cancer.

\footnotetext{
${ }^{1}$ This work was presented at the $201041^{\text {st }}$ Society of Gynecologic Oncology Annual Meeting, San Francisco, CA. ${ }^{4}$ FINANCIAL SUPPORT:

This work was generously supported by the V Foundation for Cancer Research and the Steelman Fund (Bae-Jump VL and Gehrig PA). The project described was also supported by (1) Award Number KL2RR025746 (UNC Clinical Translational Science AwardK12 Scholars Program) from the National Center for Research Resources (Bae-Jump VL) and (2) Award Number 1K23CA143154-01A1 (NIH/NCI K23 Mentored Patient-Oriented Research Career Development Grant (Bae-Jump VL).

(C) 2011 Elsevier Inc. All rights reserved.

${ }^{5}$ Corresponding Author: Victoria L. Bae-Jump, MD, PhD, Assistant Professor, University of North Carolina at Chapel Hill, Department of Obstetrics and Gynecology, Division of Gynecologic Oncology, CB\# 7572, Chapel Hill, NC 27599-7572, USA, vbae@med.unc.edu, Office Phone: +1 919843 4899, Office Fax: +1 9199662646.

3 This author contributed an equal amount of work as the first author.

Publisher's Disclaimer: This is a PDF file of an unedited manuscript that has been accepted for publication. As a service to our customers we are providing this early version of the manuscript. The manuscript will undergo copyediting, typesetting, and review of the resulting proof before it is published in its final citable form. Please note that during the production process errors may be discovered which could affect the content, and all legal disclaimers that apply to the journal pertain.
} 


\section{INTRODUCTION}

Endometrial cancer is the fourth most common cancer among women in the United States, and the death rate from this disease has alarmingly increased by $227 \%$ over the past ten years, paralleling the rise in the obesity epidemic. Type I or those tumors of endometrioid histology comprise 70-80\% of cases and are thought to arise in part from unopposed estrogen stimulation, either endogenous or exogenous. Women who develop these tumors are typically peri- or post-menopausal and often have risk factors such as obesity, hyperlipidemia, diabetes mellitus and insulin resistance, polycystic ovarian syndrome (PCOS) and hypertension. Obesity, which increases bioavailable estrogen levels by enhancing the conversion of androstenedione to estrone in peripheral adipose tissue, is a well-established risk factor for developing type I endometrial cancer and has been estimated to account for up to 40-90\% percent of type I endometrial cancer cases (1-3). Diabetes and insulin resistance have also emerged as independent risk factors for endometrial cancer (47) and have been linked to a 2-3 fold increased risk of developing this disease.

Metformin is a biguanide drug that is widely used for the treatment of type II diabetes. It is commonly thought of as an insulin sensitizer because it enhances signaling through the insulin receptor, leading to an improvement in insulin resistance, followed by a reduction in circulating insulin levels. More recently, evidence suggests that metformin's key target of action is the inhibition of hepatic gluconeogenesis (8), resulting in a secondary decline in insulin levels. Metformin inhibits complex I activity in the mitochondria (9). This leads to activation of its downstream target, AMPK, which regulates multiple signaling pathways controlling cellular proliferation, including inhibition of the mTOR pathway (10). AMPK regulates energy metabolism and is activated in response to cellular stresses that deplete cellular energy levels and increase the AMP/ATP ratio (10). AMPK functions to detect cellular energy and ensure that cell division only proceeds if there are sufficient metabolic resources to support proliferation. Once activated, AMPK restores cellular energy levels by stimulating catabolic pathways, such as glucose uptake, glycolysis and fatty acid oxidation and halting ATP-consuming processes such as fatty acid, cholesterol and protein synthesis.

AMPK activation leads to regulation of multiple downstream pathways involved in the control of cellular proliferation, including inhibition of the mTOR pathway. Given the interrelationship between these two pathways, metformin is thought to behave as a novel mTOR inhibitor and has been shown to dramatically decrease proliferation in a number of different human cancer cell lines in vitro (11-14). As demonstrated in our previous work in endometrial cancer cell lines, metformin-mediated AMPK activation decreases cell growth through inhibition of mTOR and a decrease in phosphorylation of its downstream target, S6 (11). This ultimately results in the inhibition of translation and critical mRNAs involved in cell cycle progression $(13,15)$. Treatment with metformin has also been shown to effectively repress tumor growth in xenograft animal models of breast, prostate and colon cancer (16-18).

Recent epidemiological evidence suggests that metformin lowers all cancer risk and reduces cancer incidence and deaths among diabetic patients (19-21). Furthermore, a recent retrospective cohort study of diabetic patients with early stage breast cancer found that those women receiving metformin and adjuvant chemotherapy had a higher response rate (22). This has led to the idea that metformin may have a role in cancer treatment and prevention. Multiple Phase I-III clinical trials are ongoing, most notably in breast cancer, to further test metformin's effects $(23,24)$.

mTOR inhibitors have shown their efficacy in enhancing the effects of chemotherapeutics agents in various malignancies (25-29). We have recently demonstrated that the mTOR 
inhibitor, rapamycin, potentiates the anti-proliferative effects of paclitaxel in endometrial cancer cell lines (30). Paclitaxel is a chemotherapeutic agent that stabilizes the microtubules leading to mitotic arrest and eventual cell death. Given metformin's inhibitory effects on the mTOR signaling pathway, we hypothesize that metformin similar to rapamycin may also serve as a chemosensitizer when combined with paclitaxel. In addition, we have previously demonstrated that rapamycin and metformin both profoundly suppress telomerase activity via inhibition of hTERT mRNA expression in endometrial cancer cell lines $(11,31)$, constituting another anti-tumorigenic effect shared by these agents. Thus, our goal was to examine the effects of combination therapy with metformin and paclitaxel in endometrial cancer cell lines, in regards to proliferation, apoptosis, telomerase regulation and mTOR signaling. If this combination proves synergistic, metformin and paclitaxel may have great potential in the treatment of women with advanced or recurrent endometrial cancer, a disease strongly impacted by obesity and insulin resistance.

\section{MATERIALS AND METHODS}

\section{Cell culture and reagents}

ECC-1 and Ishikawa endometrial cancer cell lines, were used in these experiments. ECC-1 cells were maintained in RPMI 1640 containing 5\% fetal bovine serum, $300 \mathrm{mM} \mathrm{L-}$ glutamine, $5 \mu \mathrm{g} / \mathrm{ml}$ bovine insulin, $10,000 \mathrm{U} / \mathrm{ml}$ penicillin and $10,000 \mu \mathrm{g} / \mathrm{ml}$ streptomycin under 5\% CO2. The Ishikawa cells were grown in MEM supplemented with 5\% fetal bovine serum, $300 \mathrm{mM} \mathrm{L}$-glutamine, $5 \mu \mathrm{g} / \mathrm{ml}$ bovine insulin, 10,000 U/ml penicillin and 10,000 $\mu \mathrm{g} /$ $\mathrm{ml}$ streptomycin under $5 \% \mathrm{CO}$.

Metformin, MTT (3-(,5-dimethylthiazol-2-yl)-2,5-diphenyltetrazolium bromide) dye and RNase A were purchased from Sigma (St. Louis, MO). The anti-cyclin D1, anti-cyclin B1, anti-phospho-AMPK, anti-pan-AMPK, anti-phospho-S6 and anti-pan-S6 antibodies were purchased from Cell Signaling (Beverly, MA). Enhanced chemiluminescence Western blotting detection reagents were purchased from Amersham (Arlington Heights, IL). All other chemicals were purchased from Sigma.

\section{Cell proliferation assays}

The ECC-1 and Ishikawa cells were plated and grown in 96-well plates at a concentration of 6000 cells/well and 8000 cells/well, respectively, for 24 hrs. These cells were subsequently treated with varying doses of metformin and paclitaxel for 24-72 hrs. Viable cell densities were determined by metabolic conversion of the dye MTT. MTT $(5 \mathrm{mg} / \mathrm{ml})$ was added to the 96 -wells plates at $10 \mu \mathrm{l} /$ well, followed by an additional hour of incubation. The MTT reaction was terminated through the addition of $100 \mu 1$ of DMSO. The results were read by measuring absorption at $595 \mathrm{~nm}$. The effect of metformin and paclitaxel was calculated as a percentage of control cell growth obtained from DMSO treated cells grown in the same 96well plates. Each experiment was performed in triplicate and repeated three times to assess for consistency of results.

\section{Flow cytometry}

Cells were plated in the appropriate media at $2.5 \times 10^{5}$ in a 6-well plate for $24 \mathrm{hrs}$. Cells were subsequently treated with metformin and paclitaxel at varying concentrations for 24 hrs. Cells were collected, washed with PBS, fixed in a 90\% methanol solution and then stored at $-20^{\circ} \mathrm{C}$ until flow cytometric analysis was performed. On the day of analysis, cells were washed and centrifuged using cold PBS, suspended in $100 \mu 1$ PBS and $10 \mu 1$ of RNase A solution $(250 \mu \mathrm{g} / \mathrm{ml})$ followed by incubation for $30 \mathrm{~min}$ at $37^{\circ} \mathrm{C}$. After incubation, $110 \mu \mathrm{l}$ of PI stain $(100 \mu \mathrm{g} / \mathrm{ml})$ was added to each tube and kept at $4^{\circ} \mathrm{C}$ for at least $30 \mathrm{~min}$ prior to analysis. Flow cytometric analysis was performed using the CyAn machine (Beckman 
Coulter, Miami, FL). ModFit software (Verity Software House, Topsham, ME) was utilized for the analysis to control for dead cells and debris. All experiments were performed in duplicate and repeated twice to assess for consistency of response.

\section{Apoptosis assay}

The cells were cultured in 6-well plates at concentrations of $2-4 \times 10^{5}$ cells/well for $24 \mathrm{hrs}$ and then treated with metformin and paclitaxel at indicated doses for an additional $24 \mathrm{hrs}$. Flow cytometry for Annexin- $\mathrm{V}$ was performed using the Annexin-V FITC kit (BioVision, Mountain View, CA). All experiments were performed in duplicate and repeated twice to assess for consistency of response.

\section{Real-time RT-PCR for hTERT mRNA expression}

Total RNA was extracted using the AIQshredder kit (Qiagen, Valencia, CA) and further purified by the RNeasy Mini-kit (Qiagen, Valencia, CA). The reverse transcription and PCR reactions were performed using the TaqMan Gold onestep RT-PCR kit in the ABI Prism 7700 Sequence Detection System (Applied Biosystems, Foster City, CA). The cells were cultured in 6-well plates at concentrations of $3 \times 10^{5}$ cells/well for $24 \mathrm{hrs}$ and then treated with metformin, paclitaxel or a combination of the two for $48 \mathrm{hrs}$ in $0.5 \%$ stripped serum. Reverse transcription was carried out at $48{ }^{\circ} \mathrm{C}$ for $30 \mathrm{~min}$. The PCR conditions consisted of a 10-min step at $95{ }^{\circ} \mathrm{C}, 40$ cycles at $95^{\circ} \mathrm{C}$ for $15 \mathrm{~s}$ each and $1 \mathrm{~min}$ at $65^{\circ} \mathrm{C}$. A housekeeping control gene acidic ribosomal phosphoprotein P0 (RPLP0, also known as 36B4) was used as an internal control to correct for differences in the amount of RNA in each sample. Primers and fluorogenic probes for hTERT and RPLP0 have been described previously (32). The standard curve for hTERT was generated by using dilutions of a known amount of cDNA synthesized by in vitro transcription of a cloned fragment. The normalized level of hTERT in each sample was estimated by a ratio of the hTERT level to the RPLP0 level, as described previously (32). Each experiment was performed in triplicate and repeated twice to assess for consistency of results.

\section{Western immunoblotting}

The Ishikawa and ECC-1 cells were plated at $3 \times 10^{5}$ cells/well in 6-well plates in their corresponding media and then treated for $16 \mathrm{~h}$ with metformin, paclitaxel or the combination of both of these agents. Cell lysates were prepared in RIPA buffer (1\% NP40, 0.5 sodium deoxycholate and $0.1 \%$ SDS). Equal amounts of protein were separated by gel electrophoresis and transferred onto a nitrocellulose membrane. The membrane was blocked with $5 \%$ nonfat dry milk and then incubated with a 1:1000 dilution of primary antibody overnight at $4{ }^{\circ} \mathrm{C}$. The membrane was then washed and incubated with a secondary peroxidase-conjugated antibody for $1 \mathrm{hr}$ after washing. Antibody binding was detected using an enhanced chemiluminescence detection system via the Alpha Innotech Imaging System (Protein Simple, Santa Clara, CA). After developing, the membrane was stripped and reprobed using antibody against $\beta$-actin and either pan-S6 or pan-AMPK to confirm equal loading. Western blot films were digitized, and band net intensities were quantified by a densitometer using the Genegynome Image System (Sygene, MD). Band net intensities were normalized to $\beta$-actin as an internal control. Each experiment was repeated three times to assess for consistency of results.

\section{Statistical analysis}

Results for experiments were normalized to the mean of the control and analyzed using the student t-test. Differences were considered significant if the $\mathrm{p}$ value was less than 0.05 $(\mathrm{p}<0.05)$ with a confidence interval of $95 \%$. 
Statistical analysis on synergy was used to evaluate the effects of combined drug treatments. The results from the MTT assays of each cell line after treatment with metformin alone, paclitaxel alone and the combination of these two agents were analyzed by the CalcuSyn for Windows computer program (Biosoft, Cambridge, UK) to determine the presence of synergy between metformin and paclitaxel.

The software uses a median-effect method, which is a well-established procedure to quantify the effects of drug combinations and to determine if there is an additive or synergistic effect of the combination. Such conclusions are based on the calculated combination index (CI) via the software; $\mathrm{CI}<1$ means a synergistic activity; whereas a CI value $=1$ and a $\mathrm{CI}>1$ mean additive and antagonistic effects, respectively.

\section{RESULTS}

\section{Synergistic anti-proliferative effects of metformin and paclitaxel}

The effects of metformin in combination with paclitaxel on cell proliferation was examined in the ECC-1 and Ishikawa endometrial cancer cell lines. Both cell lines were exposed to varying doses metformin and paclitaxel alone, followed by the combination of $0.5 \mathrm{mM}$ metformin and increasing concentrations of paclitaxel $(0.0001-100 \mathrm{nM})$ (Figure 1A and 1B). As anticipated, treatment with paclitaxel resulted in dose-dependent growth inhibition in both cell lines with $\mathrm{IC}_{50}$ values of $1-5 \mathrm{nM}$ and 5-10 $\mathrm{nM}$ for Ishikawa and ECC-1 cells, respectively. The addition of metformin at $0.5 \mathrm{mM}$ to paclitaxel led to a greater inhibition of cell proliferation than that of paclitaxel alone $(\mathrm{p}=0.0007-0.0086$ for $\mathrm{ECC}-1 ; \mathrm{p}=0.0005$ 0.0076 for Ishikawa).

Median-effect plot analyses and calculation of the multiple drug effect/CI was performed using the well-established method of Chou and Talalay (33). Simultaneous exposure of various doses of paclitaxel in combination with $0.5 \mathrm{mM}$ of metformin on both endometrial cancer cell lines resulted in a significant synergistic anti-proliferative effect with a CI of $<1$, with a range of $0.104-0.561$ for the ECC-1 cell line (Table 1). Synergy of the metformin and pacitaxel combination was also confirmed in the Ishikawa cell line for all paclitaxel concentrations greater than $0.001 \mathrm{nM}(\mathrm{CI}<1$, range of 0.275 to 0.754$)$ (Figure 1C).

\section{Effect of metformin/paclitaxel on cell cycle and apoptosis}

To evaluate the underlying mechanism of growth inhibition by metformin and paclitaxel, the cell cycle profile was analyzed after treating the ECC-1 and Ishikawa endometrial cancer cell lines with metformin, paclitaxel and the combination of these two agents for $24 \mathrm{hrs}$. In Figure 2, metformin $(0.1-5 \mathrm{mM})$ resulted in $\mathrm{G} 1$ cell cycle arrest in both the ECC-1 and Ishikawa endometrial cell lines (Figure 2A and 2B). In contrast, paclitaxel ( $0.1 \mathrm{nM}-100$ $\mathrm{nM}$ ) inhibited cell cycle progression through $\mathrm{G} 2$ arrest in both cell lines (Figure 2D and 2E). When both metformin and paclitaxel were used in combination, the overall effect in both endometrial cancer cell lines was G2 cell cycle arrest as opposed to G1 arrest (Figure $2 \mathrm{C}$ and $2 \mathrm{~F}$ ).

Cyclin B1 plays a critical role in the regulation of cell-cycle progression from $\mathrm{G} 2$ through $\mathrm{M}$ phase; and thus, accumulates after treatment with paclitaxel $(34,35)$. The synthesis of cyclin D1 is initiated during G1 and drives the G1/S phase transition, and metformin has been shown to decrease cyclin D1 expression $(16,36,37)$. Treatment with paclitaxel and metformin alone resulted in decreased cyclin D1 (28-34\% decrease for paclitaxel and 17$29 \%$ decrease for metformin) for both the ECC-1 and Ishikawa cell lines (Figure $2 \mathrm{G}$ and $2 \mathrm{H}$ ). As expected, treatment with paclitaxel led to increased cyclin B1 expression (1.2 fold for ECC-1 by densitometry and 1.4-1.6 fold for Ishikawa). Treatment with metformin in the ECC-1 cell line also resulted in increased cyclin B1 expression (1.5-1.6 fold by 
densitometry), but this effect was not seen in the Ishikawa cell line. Treatment with metformin and paclitaxel in combination resulted in greater induction of cyclin B1 than either agent alone ( 3.7 fold for the combination by densitometry versus $1.1-1.7$ fold as single agents in the Ishikawa cell line; 1.4 fold for the combination by densitometry versus $1.2-1.3$ fold as single agents in the ECC-1 cell lines) (Figure 2I). This corresponds to our cell cycle results in that the overall effect seen with the combination of metformin and paclitaxel was G2 arrest as opposed to G1 arrest.

The effect of metformin in combination with paclitaxel on apoptosis was evaluated in the endometrial cancer cell lines. Apopotosis was assessed by flow cytometry, using an antibody to Annexin V. As demonstrated in Figure 3, paclitaxel induced apoptosis in a dosedependent manner ( $\mathrm{p}=0.007-0.032$ for $\mathrm{ECC}-1 ; \mathrm{P}=0.005-0.031$ for Ishikawa). Metformin also induced apoptosis in these cell lines at higher doses of treatment $(2-5 \mathrm{mM})(\mathrm{p}=0.022$ 0.041 for ECC-1, $\mathrm{p}=0.035-0.055$ for Ishikawa). The combination of metformin $(1 \mathrm{mM})$ and paclitaxel $(10 \mathrm{nM}-100 \mathrm{nM})$ resulted in increased apoptosis, over that of either alone $(\mathrm{p}=0.031-0.041$ for ECC-1; $\mathrm{p}=0.020-0.037$ for Ishikawa). These results indicate that metformin enhances the efficacy of paclitaxel by potentially two mechanisms - increasing G2 arrest and stimulating paclitaxel-induced apoptosis.

\section{Effect of metformin/paclitaxel on hTERT mRNA level}

The maintenance of telomere length via the expression of telomerase is vital to the ability of cancer cells to remain proliferative. hTERT expression is the rate-limiting determinant of the enzymatic activity of human telomerase and is thought to be a sensitive marker of telomerase function. Real-time RT-PCR was used to quantify hTERT mRNA expression in the endometrial cancer cell lines. Treatment with metformin alone decreased hTERT mRNA expression as compared to control ( $\mathrm{p}=0.05$ for $\mathrm{ECC}-1 ; \mathrm{p}=0.0004$ for Ishikawa), whereas hTERT mRNA expression was not affected by paclitaxel treatment alone. However, the combination of metformin $(1 \mathrm{mM})$ and increasing concentrations of paclitaxel $(1-10 \mathrm{nM})$ resulted in a dose dependent decrease in hTERT mRNA expression ( $\mathrm{p}=0.006-0.028$ for ECC-1; $\mathrm{p}=.0041-0.057$ for Ishikwa). This was observed in both endometrial cancer cell lines used (Figure 4). This data suggests that the combination of metformin and paclitaxel inhibits telomerase activity by rapidly decreasing hTERT mRNA levels.

\section{The effect of metformin and metformin/paclitaxel on the mTOR pathway}

To investigate the molecular mechanisms underlying the synergistic anti-proliferative effect between metformin and paclitaxel, we characterized the effect of this combination treatment on relevant cell signaling targets. Metformin induced AMPK phosphorylation in a dosedependent manner in both endometrial cancer cell lines whereas it had no effect on the total AMPK (Figure 5A). Per densitometric analysis, phosphorylation of AMPK was increased $1.6-5.4$ fold for the ECC-1 cell line and $1.1-3.2$ fold for the Ishikawa cell line. Paclitaxel induced AMPK phosphorylation in the ECC-1 cell line (1.7 - 2.3 fold by densitometry) (Figure 5B) but had no effect on AMPK phosphorylation in the Ishikawa cell line (Figure 5B). The combination of metformin $(1 \mathrm{mM})$ and paclitaxel $(1 \mathrm{nM})$ induced AMPK phosphorylation in the ECC-1 cell line that was more than that induced by either agent alone (3.2 fold for the combination by densitometry versus $1.2-1.6$ fold as single agents) (Figure 5C). This additive effect of metformin and paclitaxel treatment on AMPK phosphorylation was not demonstrated in the Ishikawa cell line (Figure 5C).

Previous studies suggest that p70S6K is a downstream target of the mTOR pathway (38). p70S6K kinase directly phosphorylates the 40S ribosomal protein S6, which results in enhanced synthesis of proteins that contain a polypyrimidine tract in the 50-untranslated region (38). Therefore, we evaluated the effect of metformin and paclitaxel on the 
phosphorylation of the S6 ribosomal protein in both cell lines. Metformin $(0.1-1 \mathrm{mM})$ alone decreased phosporylation of S6, whereas it had no effect on total S6 (Figure 6A). Per densitometric analysis, phosphorylation of S6 was decreased 18-87\% for the ECC-1 cell line and $20-96 \%$ for the Ishikawa cell line. In contrast, paclitaxel $(0.01-10 \mathrm{nM})$ alone induced S6 phosphorylation (Figure 6B). Densitometric analysis revealed a $1.3-1.8$ fold increase in S6 phosphorylation for the ECC-1 cell line and 1.9 - 7.9 fold increase for the Ishikawa cell line. The overall effect of the combination of metformin $(1 \mathrm{mM})$ and paclitaxel $(1 \mathrm{nM})$ differed between the two cell lines. Combination treatment with metformin and paclitaxel resulted in overall inhibition of S6 phosphorylation in the Ishikawa cell line (81\% decrease by densitometry) whereas induction of S6 phosphorylation was seen in the ECC-1 cell line ( 2.1 fold increase by densitometry) (Figure 6C). However, in both cell lines, metformin effectively decreased S6 phosphorylation when compared to that of paclitaxel alone.

\section{DISCUSSION}

We have demonstrated a synergistic relationship between paclitaxel and metformin in regards to inhibition of cell proliferation and induction of apoptosis in human endometrial cancer cell lines. Treatment with metformin and paclitaxel resulted in decreased phosphorylation of S6, a critical downstream target of the mTOR pathway. Metformin consistently induced AMPK phosphorylation, but the combination of metformin and paclitaxel had more variable effects on AMPK activation. Additionally, metformin and the combination of metformin and paclitaxel decreased hTERT mRNA expression, whereas paclitaxel alone had no effect on telomerase activity. These findings suggest that the combination of metformin and paclitaxel may be an effective treatment strategy in the management of endometrial cancer patients.

Synergy was quantified using the CI equation of Chou and Talalay which allows for the evaluation of two or more chemotherapeutic agents at different concentrations and effect levels (33). Through this methodology, synergy versus antagonism of various drug combinations can be analyzed as well as their maximal anti-tumor efficacy. mTOR inhibitors such as rapamycin are thought to be potent chemotherapeutic chemosensitizers in many types of cancer cells, including our previous work in endometrial cancer cell lines (30, 39). Given the parallels in the effects of metformin and rapamycin on the mTOR signaling cascade, it is not surprising that metformin may also behave as a chemosensitizer when used in combination with cytotoxic agents. We have demonstrated that metformin has the ability to potentiate the cytotoxic effects of paclitaxel even at low doses of the latter $(0.01-0.1$ $\mathrm{nM}$ ) (Figure 1). Clinically, this may be important in decreasing toxicities associated with paclitaxel in endometrial cancer patients without significantly impacting efficacy.

Recent studies in breast, prostate and lung cancer cell lines confirm our work that the combination of metformin and paclitaxel shows great promise in the management of these various cancers $(40,41)$. The combination of metformin with paclitaxel, carboplatin or doxorubicin has been shown to prolong relapse rate in prostate and lung xenograft models (40). Most importantly from this study, metformin had comparable effects on tumor regression and prevention of relapse even when combined with a reduced dose of doxorubicin that is not usually effective as a monotherapy (40). A subsequent study found similar results in that metformin and paclitaxel resulted in decreased proliferation via cell cycle arrest in G2 phase in lung and breast cancer cell lines (41). In this same study, the combination of paclitaxel and metformin was also found to more effectively decrease tumor growth and induce apoptosis in a xenograft model of lung cancer as compared to the individual drug treatments alone (41). To our knowledge, this is the first study to demonstrate synergy betweem metformin and paclitaxel in endometrial cancer cell lines. 
Treatment with metformin alone results in G1 arrest in the endometrial cancer cell lines. In contrast, treatment with paclitaxel alone results in G2 arrest as does the combination of metformin and paclitaxel. These findings mirror that which has been demonstrated in lung and breast cancer cell lines (41). It is not clear why G2 arrest predominates with metformin and paclitaxel treatment as opposed to G1 arrest. As we reported previously and in this work, metformin had minimal effects on apoptosis except at higher doses of treatment (2-5 $\mathrm{mM}$ ), suggesting that metformin's anti-tumorigenic effect is more dependent on cell cycle arrest as opposed to cell death (11). Although $1 \mathrm{mM}$ of metformin did not significantly induce apoptosis in these endometrial cancer cell lines, treatment with metformin at this dose and paclitaxel together increased the induction of apoptosis, over that of either agent alone. The mechanism for this is not well understood. We have found this same phenomenon for the combination of rapamycin and paclitaxel in endometrial cancer cell lines and have postulated that this may result from cross talk with the mTOR pathway and the apoptotic signaling cascade activated by microtubule damage via paclitaxel, possibly through phosphorylation of the anti-apoptotic Bcl-2 protein (42).

Telomerase activation has been implicated as a fundamental step in cellular immortality and oncogenesis of many malignancies (43), including endometrial cancers $(44,45)$. Ninety percent of endometrial cancers have been found to express telomerase (44). Telomerase activation, potentially through estrogen stimulation, is thought to be an early step in the malignant transformation of the endometrium. The first study that linked metformin to the regulation of telomerase activity was from our laboratory (11), and these findings were further substantiated in this work. Paclitaxel had no effect on hTERT mRNA expression in the endometrial cancer cell lines. This is not surprising, given that paclitaxel is known to induce telomere erosion rather than to regulate telomere activity $(46,47)$. This erosion typically occurs before the onset of apoptosis. Interestingly, metformin in combination with paclitaxel had additive effects on hTERT expression as compared to metformin alone. It can been hypothesized that the combination of chemotherapeutic agents that interfere with both telomere structure and telomerase activity, such as metformin and paclitaxel, may ultimately confer a complementary anti-tumorigenic benefit that is related to regulation of hTERT mRNA expression that is distinct from their anti-proliferative effects.

As expected, metformin treatment led to the induction of AMPK phosphorylation in a dosedependent manner in the endometrial cancer cell lines. Little is known of the effects of paclitaxel on AMPK phosphorylation. We found that paclitaxel increased AMPK phosphorylation in one of the endometrial cancer cell lines but not the other. In addition, the combination of metformin and paclitaxel resulted in greater induction of AMPK phosphorylation that was more than either agent alone for the ECC-1 cell line. However, this was not demonstrated in the Ishikawa cell line, although the effects of metformin and paclitaxel on inhibition of proliferation were similar for both of these cell lines. There is no readily appreciable difference between these cell lines that would explain these differing results. Both are derived from women with type 1 endometrial cancers, and both are estrogen receptor and progesterone receptor positive. To our knowledge, only one other study has examined the effect of paclitaxel on AMPK and found that paclitaxel increased AMPK phosphorylation in lung and breast cancer cell lines (41). In this same study, the combination of metformin and paclitaxel had an additive effect on AMPK phosphorylation, similar to what we found in the ECC-1 cell line.

Despite the differences in the effect of metformin and paclitaxel on AMPK in the two endometrial cancer cell lines, the inhibition of the S6 ribosomal protein with this combination was universal. p70S6K is a critical downstream target of the mTOR pathway and directly phosphorylates the 40S ribosomal protein S6. This results in enhanced synthesis of proteins that contain a polypyrimidine tract in the 5 '-untranslated region (38). Metformin 
decreased S6 phosphorylation while paclitaxel appeared to increase S6 phosphorylation in the endometrial cancer cell lines. However, the overall effect with the metformin and paclitaxel combination was inhibition of S6 phosphorylation as compared to paclitaxel alone. The effect of paclitaxel on p70S6K and S6 is controversial with seemingly contradictory results found in regards to induction of p70S6K activity versus inhibition of phosphosphorylation in breast and ovarian cancer cell lines $(41,48)$. These findings further add to this controversy and demonstrate the complexity of effects of treatment with these agents on the signaling pathways involved as there may be many other pathways that are also simultaneously regulated.

Alterations in the mTOR pathway have been strongly implicated in endometrial cancer carcinogenesis. PTEN is a negative regulator of this pathway, and loss of PTEN expression is one of the most prevalent molecular abnormalities associated with endometrial cancers, occurring in up to $83 \%$ of type I endometrial cancers (49-51). The loss of PTEN expression may enhance sensitivity of tumor cells to the effects of mTOR inhibitors (52-54), but we were not able to address this possibility given that Ishikawa and ECC-1 cell lines are both strongly positive for PTEN (11). In addition, PIK3CA and PIK3R1 mutations have been reported a high frequency in endometrial cancer tumors (55-57), and PIK3CA mutations may be associated with increased response rates to PI3K/Akt/mTOR inhibitors (57). Thus, the mTOR pathway is thought to be a promising target for endometrial cancer treatment, and mTOR inhibitors are already in clinical trials for this disease. Given the interaction between metformin and inhibition of the mTOR pathway, there is now growing interest in metformin for endometrial cancer prevention and treatment, especially for a disease that is so strongly impacted by obesity and insulin resistance.

Obesity and diabetes have been linked to an increased risk of mortality from endometrial cancer $(4,58)$, making metformin a particularly innovative treatment strategy for this disease. However, the important biological question remains whether metformin will be universally effective in endometrial cancer treatment or more efficacious in the obese population. We postulate that the interaction between the tumor and its host environment (i.e. the obese state) may be critical in endometrial cancer development and progression, and ultimately, in response to a therapy such as metformin either alone or in combination with other chemotherapeutic agents. We currently have a preoperative window study of metformin in endometrial cancer patients that is ongoing that may help to address this question, and we plan a phase II trial of metformin and paclitaxel that is stratified for obesity status in this disease. If our hypothesis holds true, this may lead to the individualization of endometrial cancer treatment based on both tumor biology and the metabolic composition of the patient.

\section{RESEARCH HIGHLIGHTS}

1. Paclitaxel and metformin demonstrated synergy in regards to inhibition of cell proliferation in human endometrial cancer cell lines.

2. Treatment with metformin and paclitaxel resulted in decreased phosphorylation of S6, a critical downstream target of the mTOR pathway.

3. These findings suggest that metformin and paclitaxel may be an effective treatment strategy in endometrial cancer patients.

\section{REFERENCES}

1. Bergstrom A, Pisani P, Tenet V, Wolk A, Adami HO. Overweight as an avoidable cause of cancer in Europe. Int J Cancer. 2001; 91(3):421-430. PubMed PMID: 11169969. [PubMed: 11169969] 
2. Fader AN, Arriba LN, Frasure HE, von Gruenigen VE. Endometrial cancer and obesity: epidemiology, biomarkers, prevention and survivorship. Gynecol Oncol. 2009; 114(1):121-127. PubMed PMID: 19406460. [PubMed: 19406460]

3. von Gruenigen VE, Gil KM, Frasure HE, Jenison EL, Hopkins MP. The impact of obesity and age on quality of life in gynecologic surgery. Am J Obstet Gynecol. 2005; 193(4):1369-1375. PubMed PMID: 16202728. [PubMed: 16202728]

4. Chia VM, Newcomb PA, Trentham-Dietz A, Hampton JM. Obesity, diabetes, and other factors in relation to survival after endometrial cancer diagnosis. Int J Gynecol Cancer. 2007; 17(2):441-446. PubMed PMID: 17362320. [PubMed: 17362320]

5. Cust AE, Kaaks R, Friedenreich C, Bonnet F, Laville M, Lukanova A, Rinaldi S, Dossus L, Slimani N, Lundin E, Tjonneland A, Olsen A, Overvad K, Clavel-Chapelon F, Mesrine S, Joulin V, Linseisen J, Rohrmann S, Pischon T, Boeing H, Trichopoulos D, Trichopoulou A, Benetou V, Palli D, Berrino F, Tumino R, Sacerdote C, Mattiello A, Quiros JR, Mendez MA, Sanchez MJ, Larranaga N, Tormo MJ, Ardanaz E, Bueno-de-Mesquita HB, Peeters PH, van Gils CH, Khaw KT, Bingham S, Allen N, Key T, Jenab M, Riboli E. Plasma adiponectin levels and endometrial cancer risk in preand postmenopausal women. J Clin Endocrinol Metab. 2007; 92(1):255-263. PubMed PMID: 17062769. [PubMed: 17062769]

6. Soliman PT, Wu D, Tortolero-Luna G, Schmeler KM, Slomovitz BM, Bray MS, Gershenson DM, $\mathrm{Lu}$ KH. Association between adiponectin, insulin resistance, and endometrial cancer. Cancer. 2006; 106(11):2376-2381. PubMed PMID: 16639730. [PubMed: 16639730]

7. Friberg E, Mantzoros CS, Wolk A. Diabetes and risk of endometrial cancer: a population-based prospective cohort study. Cancer Epidemiol Biomarkers Prev. 2007; 16(2):276-280. PubMed PMID: 17301260. [PubMed: 17301260]

8. Shaw RJ, Lamia KA, Vasquez D, Koo SH, Bardeesy N, Depinho RA, Montminy M, Cantley LC. The kinase LKB1 mediates glucose homeostasis in liver and therapeutic effects of metformin. Science. 2005; 310(5754):1642-1646. PubMed PMID: 16308421. [PubMed: 16308421]

9. Brunmair B, Staniek K, Gras F, Scharf N, Althaym A, Clara R, Roden M, Gnaiger E, Nohl H, Waldhausl W, Furnsinn C. Thiazolidinediones, like metformin, inhibit respiratory complex I: a common mechanism contributing to their antidiabetic actions? Diabetes. 2004; 53(4):1052-1059. PubMed PMID: 15047621. [PubMed: 15047621]

10. Hadad SM, Fleming S, Thompson AM. Targeting AMPK: A new therapeutic opportunity in breast cancer. Crit Rev Oncol Hematol. 2008 PubMed PMID: 18343152.

11. Cantrell LA, Zhou C, Mendivil A, Malloy KM, Gehrig PA, Bae-Jump VL. Metformin is a potent inhibitor of endometrial cancer cell proliferation--implications for a novel treatment strategy. Gynecol Oncol. 2010; 116(1):92-98. PubMed PMID: 19822355; PubMed Central PMCID: PMC2789879. [PubMed: 19822355]

12. Gotlieb WH, Saumet J, Beauchamp MC, Gu J, Lau S, Pollak MN, Bruchim I. In vitro metformin anti-neoplastic activity in epithelial ovarian cancer. Gynecol Oncol. 2008; 110(2):246-250. PubMed PMID: 18495226. [PubMed: 18495226]

13. Zakikhani M, Dowling R, Fantus IG, Sonenberg N, Pollak M. Metformin is an AMP kinasedependent growth inhibitor for breast cancer cells. Cancer Res. 2006; 66(21):10269-10273. PubMed PMID: 17062558. [PubMed: 17062558]

14. Zakikhani M, Dowling RJ, Sonenberg N, Pollak MN. The effects of adiponectin and metformin on prostate and colon neoplasia involve activation of AMP-activated protein kinase. Cancer Prev Res (Phila Pa). 2008; 1(5):369-375. PubMed PMID: 19138981.

15. Dowling RJ, Zakikhani M, Fantus IG, Pollak M, Sonenberg N. Metformin inhibits mammalian target of rapamycin-dependent translation initiation in breast cancer cells. Cancer Res. 2007; 67(22):10804-10812. PubMed PMID: 18006825. [PubMed: 18006825]

16. Ben Sahra I, Laurent K, Loubat A, Giorgetti-Peraldi S, Colosetti P, Auberger P, Tanti JF, Le Marchand-Brustel Y, Bost F. The antidiabetic drug metformin exerts an antitumoral effect in vitro and in vivo through a decrease of cyclin D1 level. Oncogene. 2008; 27(25):3576-3586. PubMed PMID: 18212742. [PubMed: 18212742]

17. Buzzai M, Jones RG, Amaravadi RK, Lum JJ, DeBerardinis RJ, Zhao F, Viollet B, Thompson CB. Systemic treatment with the antidiabetic drug metformin selectively impairs p53-deficient tumor 
cell growth. Cancer Res. 2007; 67(14):6745-6752. PubMed PMID: 17638885. [PubMed: 17638885]

18. Hirsch HA, Iliopoulos D, Tsichlis PN, Struhl K. Metformin selectively targets cancer stem cells, and acts together with chemotherapy to block tumor growth and prolong remission. Cancer Res. 2009; 69(19):7507-7511. PubMed PMID: 19752085. [PubMed: 19752085]

19. Evans JM, Donnelly LA, Emslie-Smith AM, Alessi DR, Morris AD. Metformin and reduced risk of cancer in diabetic patients. Bmj. 2005; 330(7503):1304-1305. PubMed PMID: 15849206. [PubMed: 15849206]

20. Bowker SL, Majumdar SR, Veugelers P, Johnson JA. Increased cancer-related mortality for patients with type 2 diabetes who use sulfonylureas or insulin. Diabetes Care. 2006; 29(2):254258. PubMed PMID: 16443869. [PubMed: 16443869]

21. Libby G, Donnelly LA, Donnan PT, Alessi DR, Morris AD, Evans JM. New users of metformin are at low risk of incident cancer: a cohort study among people with type 2 diabetes. Diabetes Care. 2009; 32(9):1620-1625. PubMed PMID: 19564453. [PubMed: 19564453]

22. Jiralerspong S, Palla SL, Giordano SH, Meric-Bernstam F, Liedtke C, Barnett CM, Hsu L, Hung MC, Hortobagyi GN, Gonzalez-Angulo AM. Metformin and pathologic complete responses to neoadjuvant chemotherapy in diabetic patients with breast cancer. J Clin Oncol. 2009; 27(20): 3297-3302. PubMed PMID: 19487376. [PubMed: 19487376]

23. Wysocki PJ, Wierusz-Wysocka B. Obesity, hyperinsulinemia and breast cancer: novel targets and a novel role for metformin. Expert Rev Mol Diagn. 10(4):509-519. PubMed PMID: 20465505. [PubMed: 20465505]

24. Gonzalez-Angulo AM, Meric-Bernstam F. Metformin: a therapeutic opportunity in breast cancer. Clin Cancer Res. 16(6):1695-1700. PubMed PMID: 20215559. [PubMed: 20215559]

25. Wu C, Wangpaichitr M, Feun L, Kuo MT, Robles C, Lampidis T, Savaraj N. Overcoming cisplatin resistance by mTOR inhibitor in lung cancer. Mol Cancer. 2005; 4(1):25. PubMed PMID: 16033649. [PubMed: 16033649]

26. Mondesire WH, Jian W, Zhang H, Ensor J, Hung MC, Mills GB, Meric-Bernstam F. Targeting mammalian target of rapamycin synergistically enhances chemotherapy-induced cytotoxicity in breast cancer cells. Clin Cancer Res. 2004; 10(20):7031-7042. PubMed PMID: 15501983. [PubMed: 15501983]

27. Mabuchi S, Altomare DA, Cheung M, Zhang L, Poulikakos PI, Hensley HH, Schilder RJ, Ozols RF, Testa JR. RAD001 inhibits human ovarian cancer cell proliferation, enhances cisplatininduced apoptosis, and prolongs survival in an ovarian cancer model. Clin Cancer Res. 2007; 13(14):4261-4270. PubMed PMID: 17634556. [PubMed: 17634556]

28. Faried LS, Faried A, Kanuma T, Nakazato T, Tamura T, Kuwano H, Minegishi T. Inhibition of the mammalian target of rapamycin (mTOR) by rapamycin increases chemosensitivity of CaSki cells to paclitaxel. Eur J Cancer. 2006; 42(7):934-947. PubMed PMID: 16540312. [PubMed: 16540312]

29. Geoerger B, Kerr K, Tang CB, Fung KM, Powell B, Sutton LN, Phillips PC, Janss AJ. Antitumor activity of the rapamycin analog CCI-779 in human primitive neuroectodermal tumor/ medulloblastoma models as single agent and in combination chemotherapy. Cancer Res. 2001; 61(4):1527-1532. PubMed PMID: 11245461. [PubMed: 11245461]

30. Shafer A, Zhou C, Gehrig PA, Boggess JF, Bae-Jump VL. Rapamycin potentiates the effects of paclitaxel in endometrial cancer cells through inhibition of cell proliferation and induction of apoptosis. Int J Cancer. 2010; 126(5):1144-1154. PubMed PMID: 19688827; PubMed Central PMCID: PMC2818608. [PubMed: 19688827]

31. Zhou C, Gehrig PA, Whang YE, Boggess JF. Rapamycin inhibits telomerase activity by decreasing the hTERT mRNA level in endometrial cancer cells. Mol Cancer Ther. 2003; 2(8):789-795. PubMed PMID: 12939469. [PubMed: 12939469]

32. Bieche I, Nogues C, Paradis V, Olivi M, Bedossa P, Lidereau R, Vidaud M. Quantitation of hTERT gene expression in sporadic breast tumors with a real-time reverse transcriptionpolymerase chain reaction assay. Clin Cancer Res. 2000; 6(2):452-459. PubMed PMID: 10690523. [PubMed: 10690523] 
33. Chou TC, Talalay P. Quantitative analysis of dose-effect relationships: the combined effects of multiple drugs or enzyme inhibitors. Adv Enzyme Regul. 1984; 22:27-55. PubMed PMID: 6382953. [PubMed: 6382953]

34. Panvichian R, Orth K, Pilat MJ, Day ML, Day KC, Yee C, Kamradt JM, Pienta KJ. Signaling network of paclitaxel-induced apoptosis in the LNCaP prostate cancer cell line. Urology. 1999; 54(4):746-752. PubMed PMID: 10510942. [PubMed: 10510942]

35. Ling YH, Consoli U, Tornos C, Andreeff M, Perez-Soler R. Accumulation of cyclin B1, activation of cyclin B1-dependent kinase and induction of programmed cell death in human epidermoid carcinoma KB cells treated with taxol. Int J Cancer. 1998; 75(6):925-932. PubMed PMID: 9506539. [PubMed: 9506539]

36. Rattan R, Giri S, Hartmann LC, Shridhar V. Metformin attenuates ovarian cancer cell growth in an AMP-kinase dispensable manner. Journal of cellular and molecular medicine. 2011; 15(1):166178. PubMed PMID: 19874425. [PubMed: 19874425]

37. Alimova IN, Liu B, Fan Z, Edgerton SM, Dillon T, Lind SE, Thor AD. Metformin inhibits breast cancer cell growth, colony formation and induces cell cycle arrest in vitro. Cell Cycle. 2009; 8(6): 909-915. PubMed PMID: 19221498. [PubMed: 19221498]

38. Jefferies HB, Fumagalli S, Dennis PB, Reinhard C, Pearson RB, Thomas G. Rapamycin suppresses 5'TOP mRNA translation through inhibition of p70s6k. EMBO J. 1997; 16(12):3693-3704. PubMed PMID: 9218810; PubMed Central PMCID: PMC1169993. [PubMed: 9218810]

39. Bae-Jump VL, Zhou C, Boggess JF, Gehrig PA. Synergistic effect of rapamycin and cisplatin in endometrial cancer cells. Cancer. 2009; 115(17):3887-3896. PubMed PMID: 19484784. [PubMed: 19484784]

40. Iliopoulos D, Hirsch HA, Struhl K. Metformin decreases the dose of chemotherapy for prolonging tumor remission in mouse xenografts involving multiple cancer cell types. Cancer Res. 71(9): 3196-3201. PubMed PMID: 21415163. [PubMed: 21415163]

41. Rocha GZ, Dias MM, Ropelle ER, Osorio-Costa F, Rossato FA, Vercesi AE, Saad MJ, Carvalheira JB. Metformin Amplifies Chemotherapy-Induced AMPK Activation and Antitumoral Growth. Clin Cancer Res. 17(12):3993-4005. PubMed PMID: 21543517. [PubMed: 21543517]

42. Asnaghi L, Calastretti A, Bevilacqua A, D'Agnano I, Gatti G, Canti G, Delia D, Capaccioli S, Nicolin A. Bcl-2 phosphorylation and apoptosis activated by damaged microtubules require mTOR and are regulated by Akt. Oncogene. 2004; 23(34):5781-5791. PubMed PMID: 15208671. [PubMed: 15208671]

43. Stewart SA, Weinberg RA. Telomerase and human tumorigenesis. Semin Cancer Biol. 2000; 10(6):399-406. PubMed PMID: 11170862. [PubMed: 11170862]

44. Yokoyama Y, Takahashi Y, Shinohara A, Lian Z, Tamaya T. Telomerase activity in the female reproductive tract and neoplasms. Gynecol Oncol. 1998; 68(2):145-149. PubMed PMID: 9514809. [PubMed: 9514809]

45. Zheng PS, Iwasaka T, Yamasaki F, Ouchida M, Yokoyama M, Nakao Y, Fukuda K, Matsuyama T, Sugimori H. Telomerase activity in gynecologic tumors. Gynecol Oncol. 1997; 64(1):171-175. PubMed PMID: 8995569. [PubMed: 8995569]

46. Mo Y, Gan Y, Song S, Johnston J, Xiao X, Wientjes MG, Au JL. Simultaneous targeting of telomeres and telomerase as a cancer therapeutic approach. Cancer Res. 2003; 63(3):579-585. PubMed PMID: 12566299. [PubMed: 12566299]

47. Multani AS, Li C, Ozen M, Imam AS, Wallace S, Pathak S. Cell-killing by paclitaxel in a metastatic murine melanoma cell line is mediated by extensive telomere erosion with no decrease in telomerase activity. Oncol Rep. 1999; 6(1):39-44. PubMed PMID: 9864398. [PubMed: 9864398]

48. Le XF, Hittelman WN, Liu J, McWatters A, Li C, Mills GB, Bast RC Jr. Paclitaxel induces inactivation of p70 S6 kinase and phosphorylation of Thr421 and Ser424 via multiple signaling pathways in mitosis. Oncogene. 2003; 22(4):484-497. PubMed PMID: 12555062. [PubMed: 12555062]

49. Mutter GL, Lin MC, Fitzgerald JT, Kum JB, Baak JP, Lees JA, Weng LP, Eng C. Altered PTEN expression as a diagnostic marker for the earliest endometrial precancers. J Natl Cancer Inst. 2000; 92(11):924-930. PubMed PMID: 10841828. [PubMed: 10841828] 
50. An HJ, Lee YH, Cho NH, Shim JY, Kim JY, Lee C, Kim SJ. Alteration of PTEN expression in endometrial carcinoma is associated with down-regulation of cyclin-dependent kinase inhibitor, p27. Histopathology. 2002; 41(5):437-445. PubMed PMID: 12405911. [PubMed: 12405911]

51. Terakawa N, Kanamori Y, Yoshida S. Loss of PTEN expression followed by Akt phosphorylation is a poor prognostic factor for patients with endometrial cancer. Endocr Relat Cancer. 2003; 10(2): 203-208. PubMed PMID: 12790783. [PubMed: 12790783]

52. Podsypanina K, Lee RT, Politis C, Hennessy I, Crane A, Puc J, Neshat M, Wang H, Yang L, Gibbons J, Frost P, Dreisbach V, Blenis J, Gaciong Z, Fisher P, Sawyers C, Hedrick-Ellenson L, Parsons R. An inhibitor of mTOR reduces neoplasia and normalizes p70/S6 kinase activity in Pten +/- mice. Proc Natl Acad Sci U S A. 2001; 98(18):10320-10325. PubMed PMID: 11504907. [PubMed: 11504907]

53. Grunwald V, DeGraffenried L, Russel D, Friedrichs WE, Ray RB, Hidalgo M. Inhibitors of mTOR reverse doxorubicin resistance conferred by PTEN status in prostate cancer cells. Cancer Res. 2002; 62(21):6141-6145. PubMed PMID: 12414639. [PubMed: 12414639]

54. Neshat MS, Mellinghoff IK, Tran C, Stiles B, Thomas G, Petersen R, Frost P, Gibbons JJ, Wu H, Sawyers CL. Enhanced sensitivity of PTEN-deficient tumors to inhibition of FRAP/mTOR. Proc Natl Acad Sci U S A. 2001; 98(18):10314-10319. PubMed PMID: 11504908; PubMed Central PMCID: PMC56958. [PubMed: 11504908]

55. Urick ME, Rudd ML, Godwin AK, Sgroi D, Merino M, Bell DW. PIK3R1 (p85\{alpha\}) Is Somatically Mutated at High Frequency in Primary Endometrial Cancer. Cancer Res. 71(12): 4061-4067. PubMed PMID: 21478295. [PubMed: 21478295]

56. Rudd ML, Price JC, Fogoros S, Godwin AK, Sgroi DC, Merino MJ, Bell DW. A unique spectrum of somatic PIK3CA (p110alpha) mutations within primary endometrial carcinomas. Clin Cancer Res. 17(6):1331-1340. PubMed PMID: 21266528. [PubMed: 21266528]

57. Janku F, Tsimberidou AM, Garrido-Laguna I, Wang X, Luthra R, Hong DS, Naing A, Falchook GS, Moroney JW, Piha-Paul SA, Wheler JJ, Moulder SL, Fu S, Kurzrock R. PIK3CA mutations in patients with advanced cancers treated with PI3K/AKT/mTOR axis inhibitors. Mol Cancer Ther. 10(3):558-565. PubMed PMID: 21216929. [PubMed: 21216929]

58. Steiner E, Plata K, Interthal C, Schmidt M, Faldum A, Hengstler JG, Sakuragi N, Watari H, Yamamoto R, Kolbl H. Diabetes mellitus is a multivariate independent prognostic factor in endometrial carcinoma: a clinicopathologic study on 313 patients. European journal of gynaecological oncology. 2007; 28(2):95-97. PubMed PMID: 17479668. [PubMed: 17479668] 
A
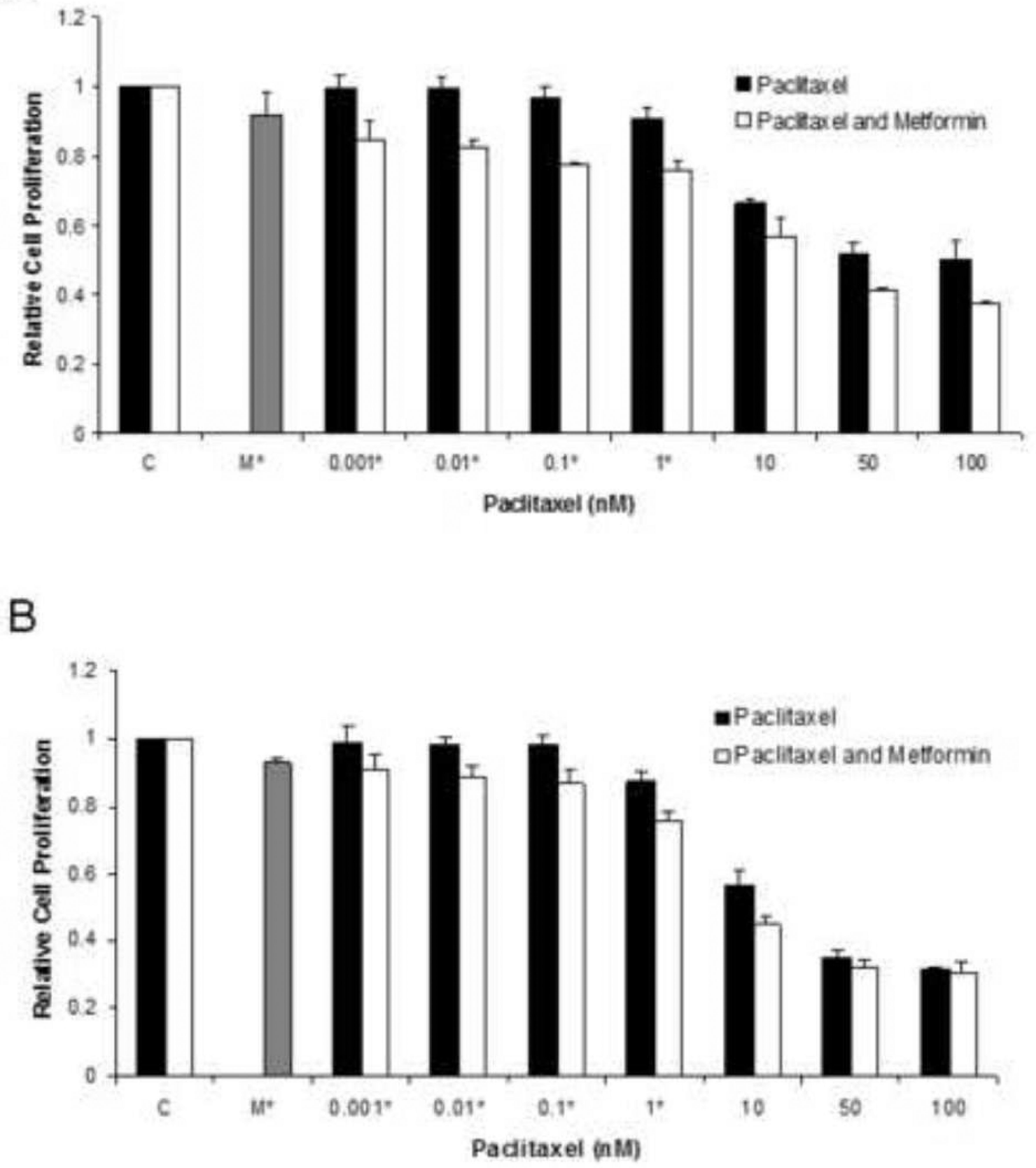


\section{Combination Index (CI) Values for the ECC-1 and Ishikawa Cell Lines Treated with Metformin and Paclitaxel}

\begin{tabular}{|l|l|l|l|}
\hline Metformin (mM) & Paclitaxel (nM) & $\begin{array}{l}\text { CI for ECC-1 Cell } \\
\text { Line }\end{array}$ & $\begin{array}{l}\text { CI for Ishikawa } \\
\text { Cell Line }\end{array}$ \\
\hline 0.5 & 0.001 & 0.185 & 1.045 \\
\hline 0.5 & 0.01 & 0.150 & 0.618 \\
\hline 0.5 & 0.1 & 0.104 & 0.610 \\
\hline 0.5 & 1 & 0.214 & 0.479 \\
\hline 0.5 & 10 & 0.272 & 0.275 \\
\hline 0.5 & 50 & 0.391 & 0.448 \\
\hline 0.5 & 100 & 0.561 & 0.754 \\
\hline
\end{tabular}

Figure 1. Metformin increased sensitivity to paclitaxel in the ECC-1 and Ishikawa cell lines The ECC-1 (A) and Ishikawa (B) cells were cultured in the presence of varying concentrations of paclitaxel $(0.001-10 \mathrm{nM})$ and $0.5 \mathrm{mM}$ metformin in regular medium for 48 hours. The inhibition of cell growth was determined by MTT assay. The results are shown as the mean \pm SE of triplicate samples and are representative of 3 independent experiments. Statistically significant results are marked with an *. (C) Combination Index (CI) values for the ECC-1 and Ishikawa cell lines treated with metformin and paclitaxel. A CI of $<1$ indicates synergy between two chemotherapeutic agents. 
A

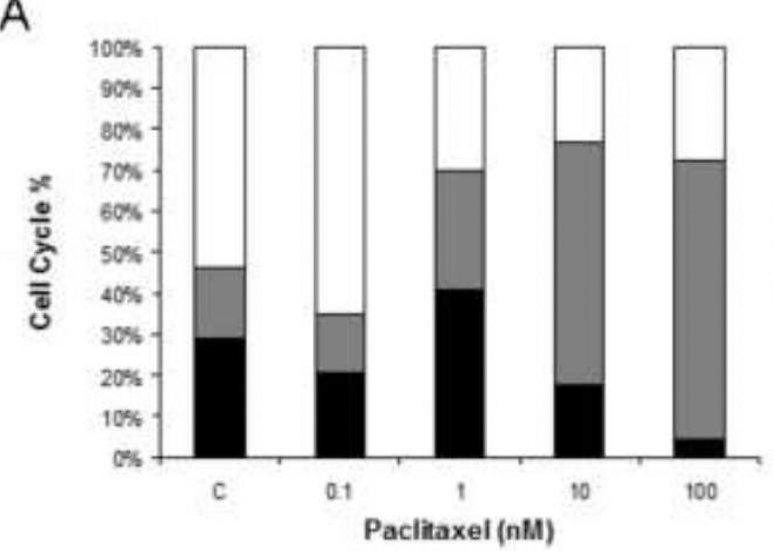

D

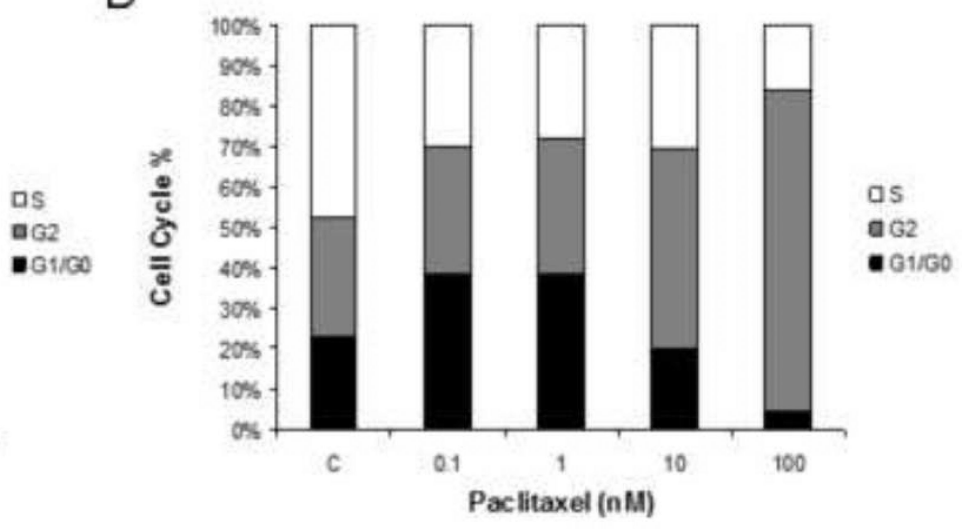

B

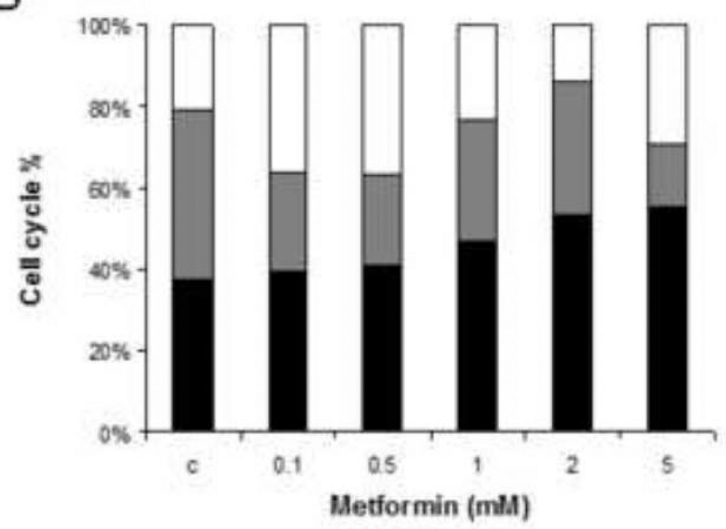

C

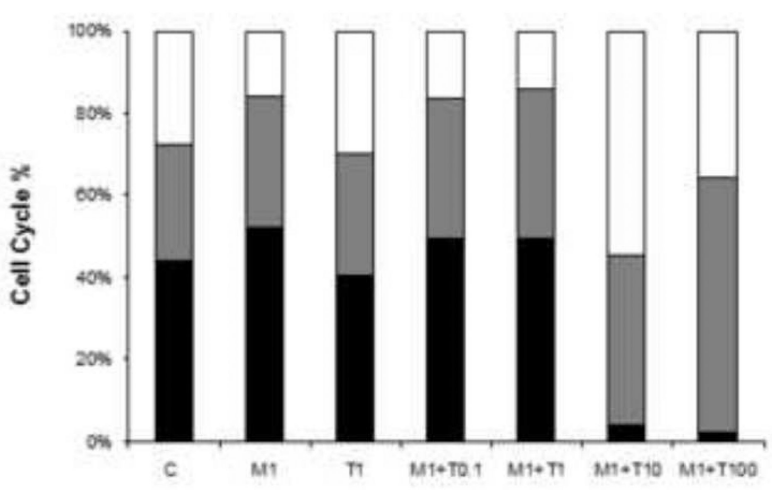

ECC-1 Cell line
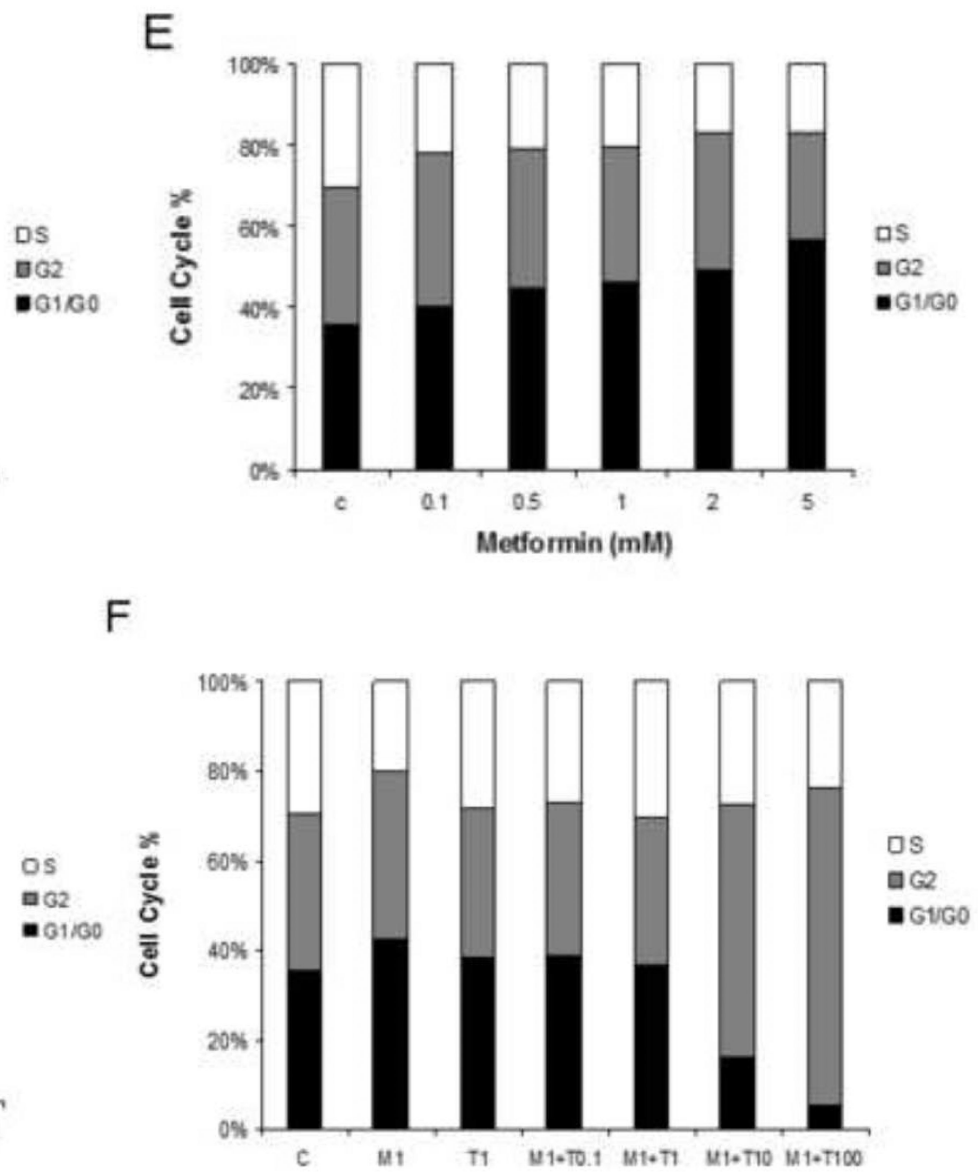

Ishikawa Cell line

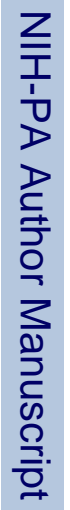


G ECC-1 Ishikawa

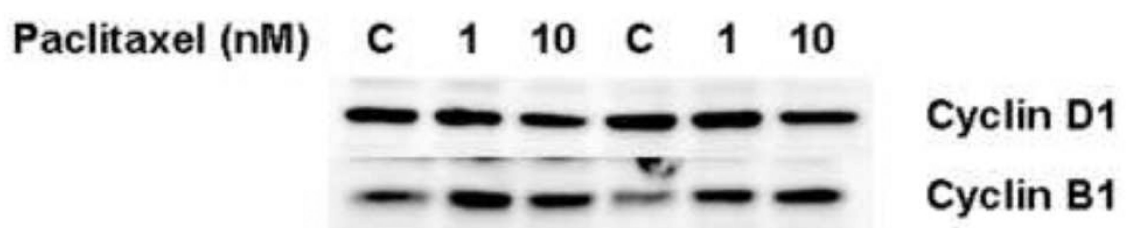

$\mathrm{H}$

$\begin{array}{lllllll}\text { Metformin (mM) } & \text { C } & 0.1 & 1 & \text { C } & 0.1 & 1\end{array}$
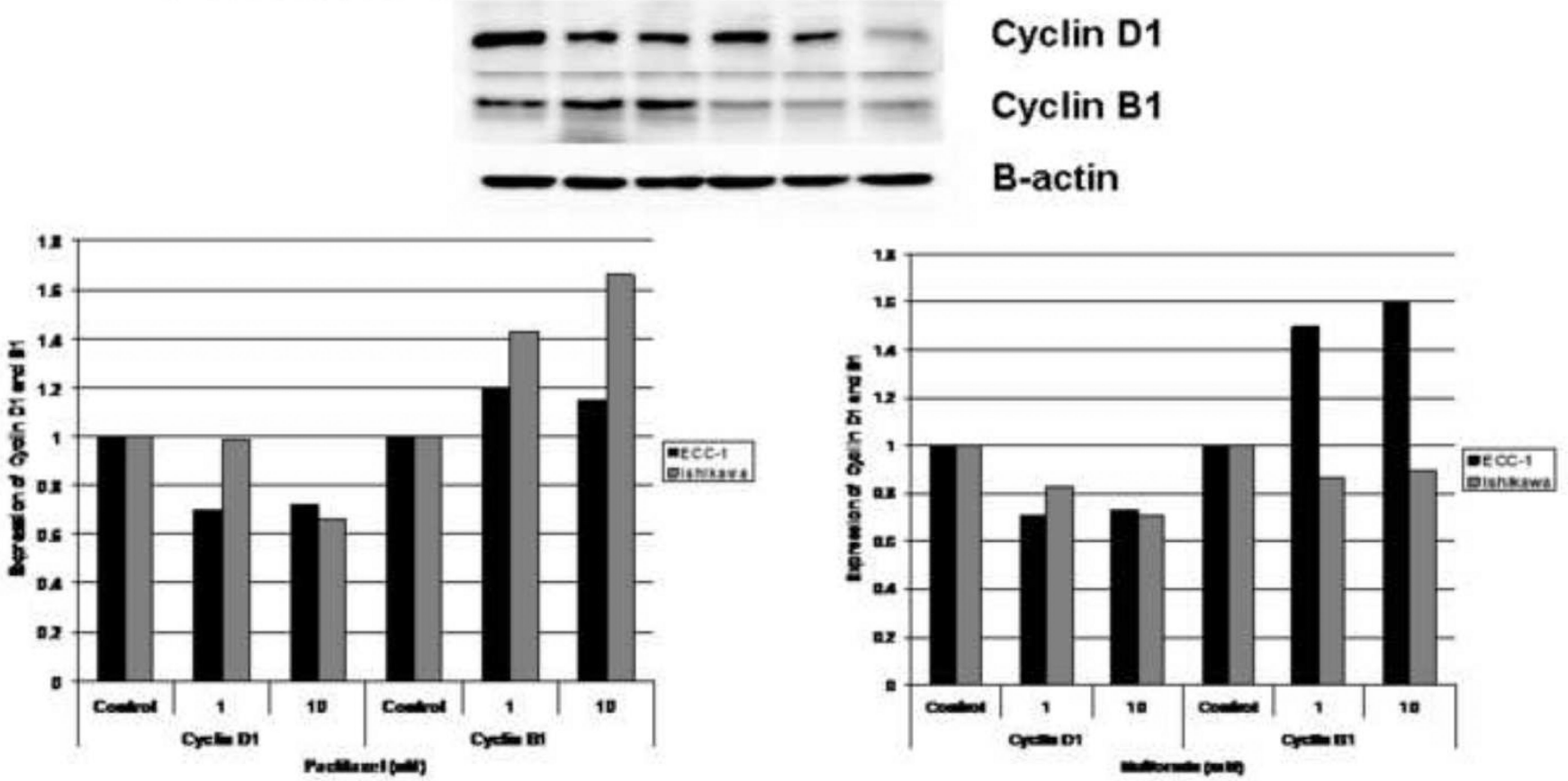

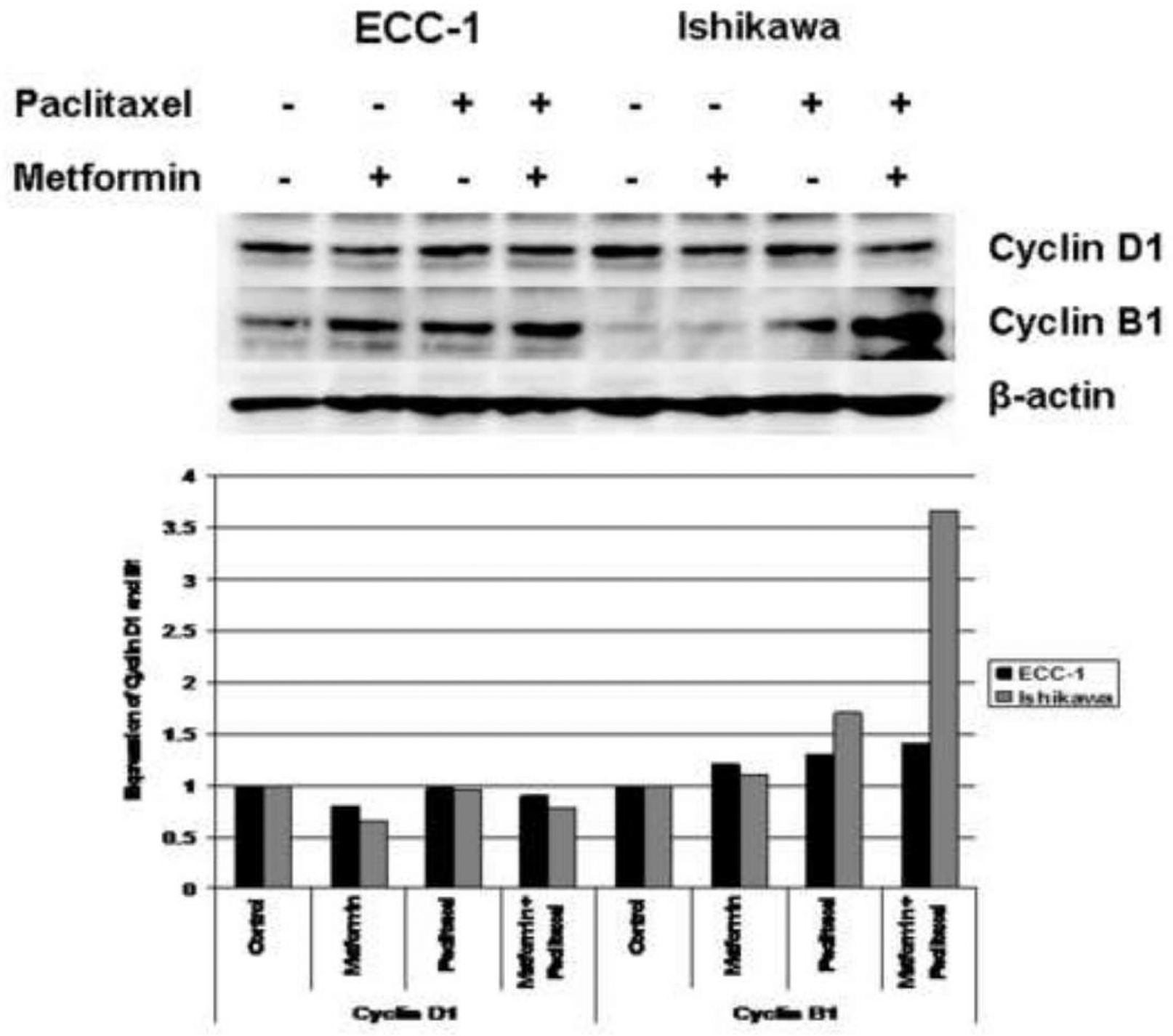

Figure 2. The effect of paclitaxel and metformin on cell cycle progression in the ECC-1 and Ishikawa cell lines

ECC-1 (A, B, C) and Ishikawa (D, E, F) was cultured for 24 hours and then treated with different concentrations of paclitaxel $(0.1-100 \mathrm{nM})$ and metformin $(0.1-5 \mathrm{mM})$ as indicated for 24 hours. Cell cycle analysis was performed by flow cytometry $(\mathrm{M}=$ metformin; $\mathrm{T}$ = paclitaxel). Results shown are representative of two independent experiments. Treatment with metformin led to G1 arrest whereas treatment with paclitaxel led to $\mathrm{G} 2$ arrest. Combination treatment with both these agents resulted in overall G2 arrest. The effect of paclitaxel and metformin on cyclin D1 and cyclin B1 expression was also examined in the Ishikawa and ECC-1 cell lines by Western Immunoblotting. The cells were treated with paclitaxel (Figure 2G), metformin (Figure $2 \mathrm{H}$ ) or both in combination (1 mM metformin and 1nM paclitaxel, Figure 2I) for 48 hours. Paclitaxel treatment resulted in decreased cyclin D1 and increased cyclin B1 expression. Metformin treatment resulted in decreased cyclin D1 expression in both cell lines, but only increased cyclin B1 expression in the ECC-1 cell line. The combination of paclitaxel and metformin treatment led to an overall increase in cyclin B1 that was greater than the effect of either agent alone. The densitometric analysis of band intensities, as normalized to the $\beta$-actin internal control, is represented 
under each Western blot and signifies the fold increase or decrease in cyclin D1 or cyclin B1 expression. 
A
D
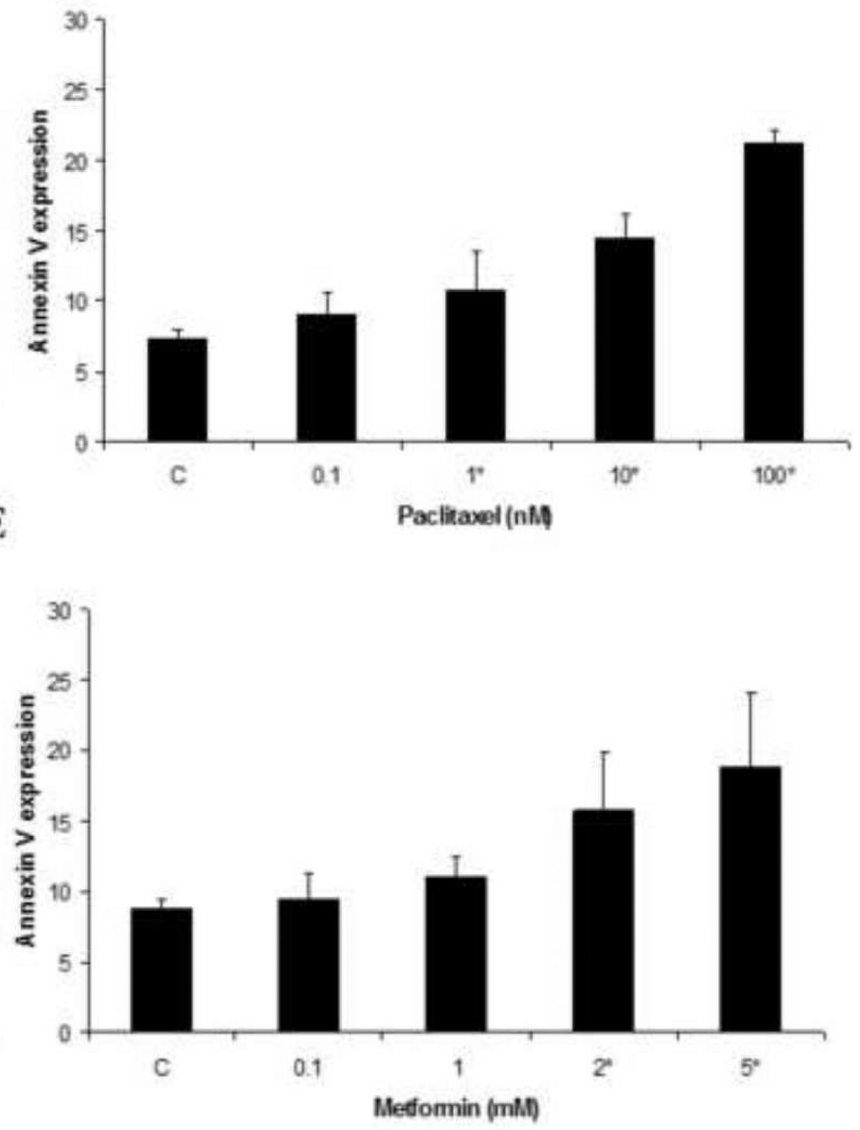

$\mathrm{F}$

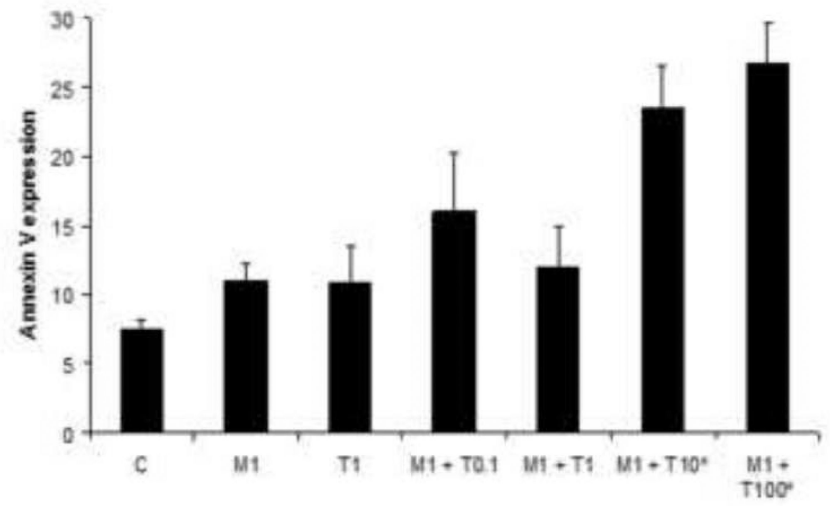

Ishikawa Cell line

Figure 3. Paclitaxel and metformin increases apoptosis in the ECC-1 and Ishikawa cell lines The ECC-1 (A, B , C) and Ishikawa (D, E, F) cells were cultured for 24 hours and then treated with different concentrations of paclitaxel $(0.1-100 \mathrm{nM})$ and metformin $(0.1-5$ $\mathrm{mM})$ as indicated for 24 hours. Apoptosis was measured by annexin $\mathrm{V}$ assay $(\mathrm{M}=$ 
metformin; $\mathrm{T}=$ paclitaxel). The results are shown as the mean $\pm \mathrm{SE}$ of two independent experiments. Statistically significant results are marked with an *. 
A
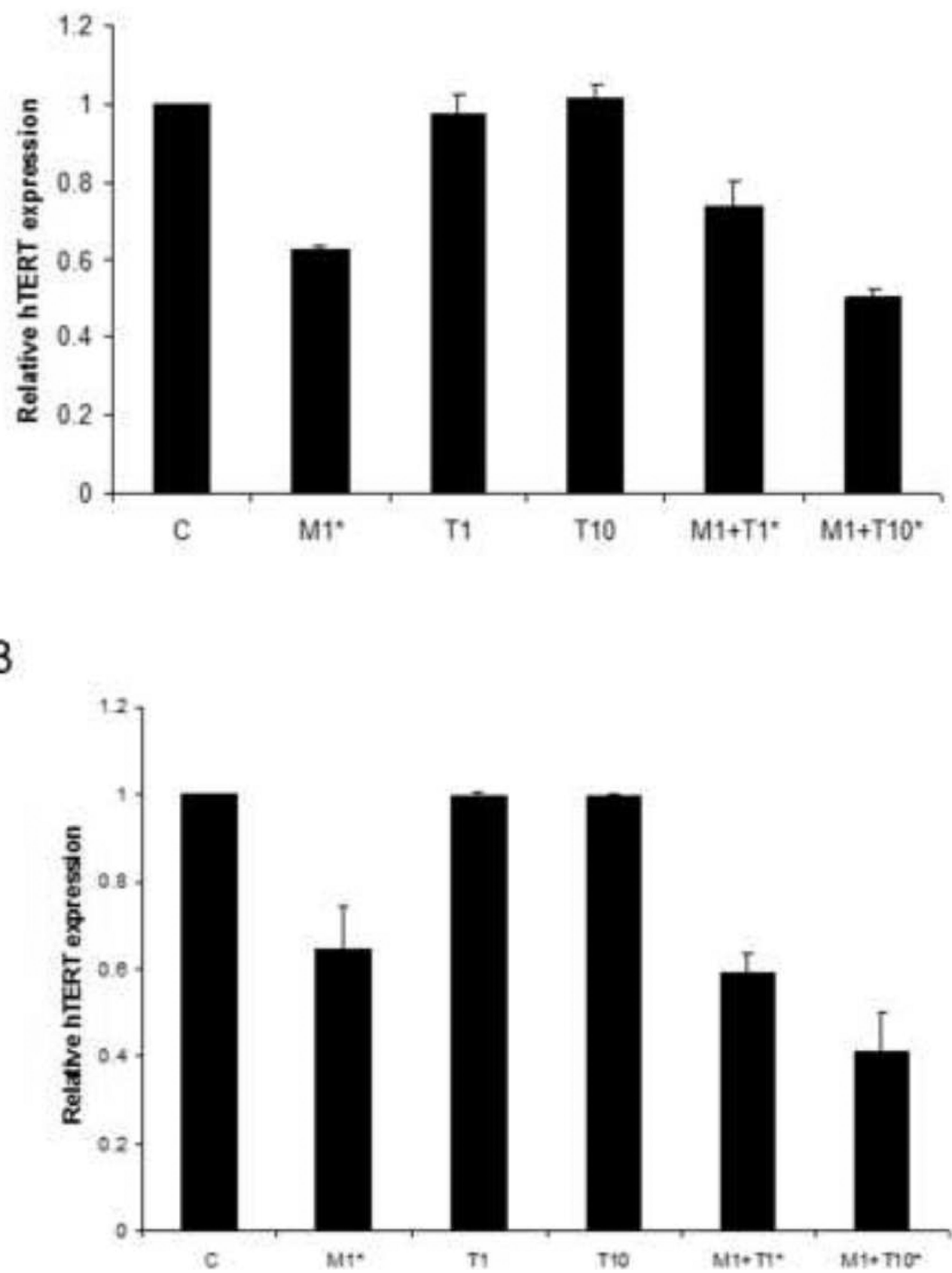

Figure 4. Metformin but not paclitaxel decreased hTERT mRNA expression in the ECC-1 (A) and Ishikawa (B) cell lines. However, there was an additive effect on inhibition of hTERT mRNA expression when both metformin and paclitaxel were used in combination Both cell lines were cultured for 24 hours and then treated with the indicated concentrations of metformin $(1 \mathrm{mM})$ and paclitaxel $(1-10 \mathrm{nM})$ for an additional 24 hours. hTERT expression was determined by real-time RT-PCR $(\mathrm{M}=$ metformin; $\mathrm{T}=$ paclitaxel $)$. The results are shown as the mean $\pm \mathrm{SE}$ of two independent experiments. Statistically significant results are marked with an $*$. 
A
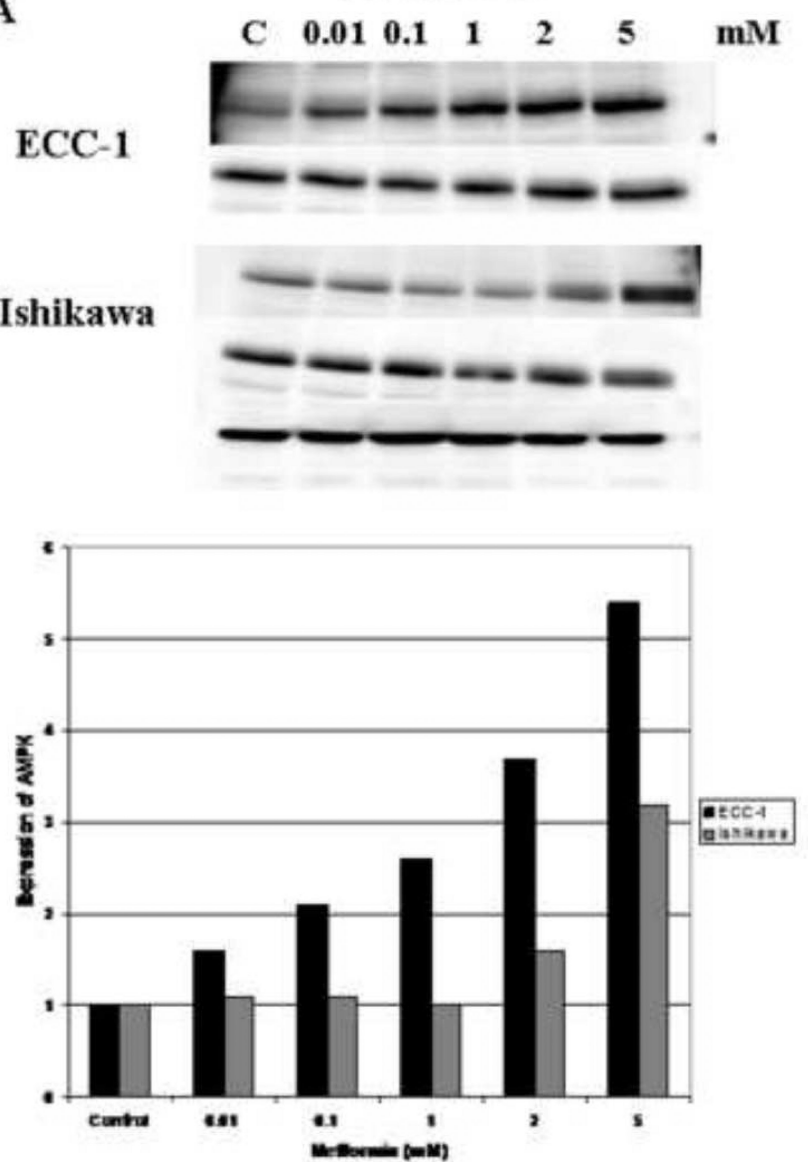

B

\section{Paclitaxel}
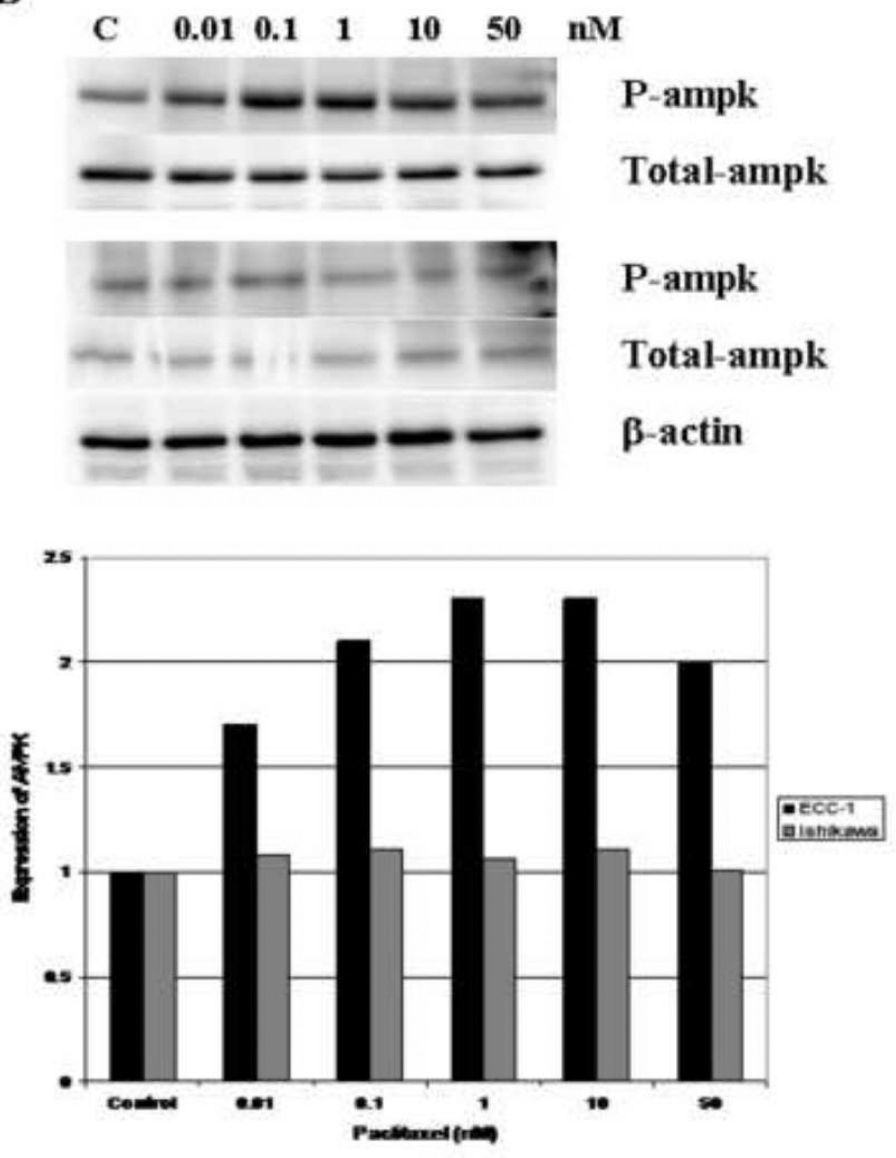

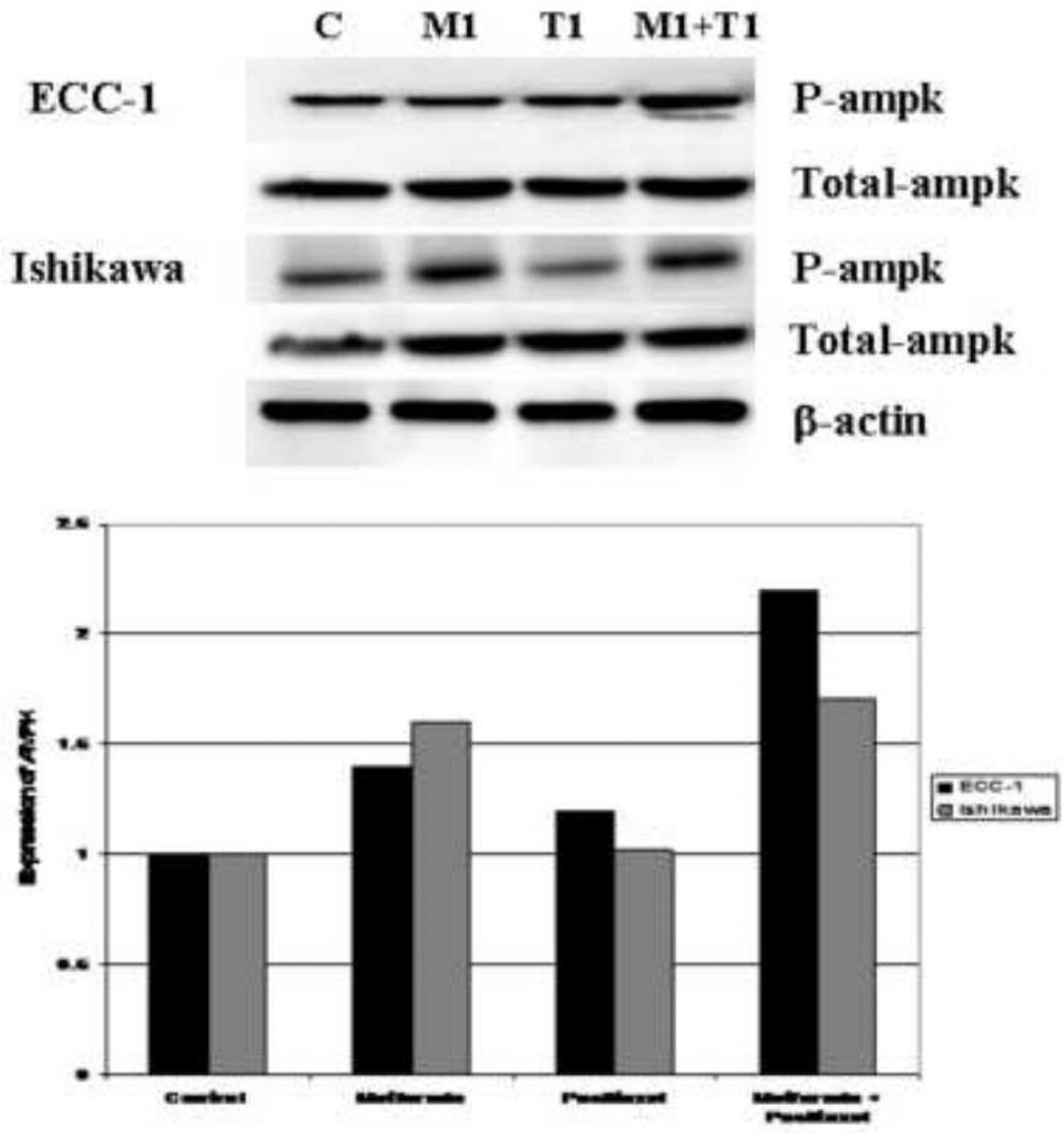

Figure 5. The effects of metformin and paclitaxel on phosphorylation of AMPK in the Ishikawa and ECC-1 cell lines

Metformin induced AMPK phosphorylation in a dose-dependent manner in both endometrial cancer cell lines (A). Paclitaxel induced AMPK phosphorylation in the ECC-1 cell line (B); however, it had no effect on AMPK phosphorylation in the Ishikawa cell line (B). In the ECC-1 cell line, the combination of paclitaxel $(1 \mathrm{nM})$ and metformin $(1 \mathrm{mM})$ increased AMPK phosphorylation to more than that of either agent alone (C). This additive effect on AMPK phosphorylation was not demonstrated in the Ishikawa cell line (C). The densitometric analysis of band intensities, as normalized to the $\beta$-actin internal control, is 
represented under each Western blot and signifies the fold increase or decrease in phosphorylated AMPK expression. $(\mathrm{P}$-ampk = phosphorylated ampk) 
$\mathbf{A}$

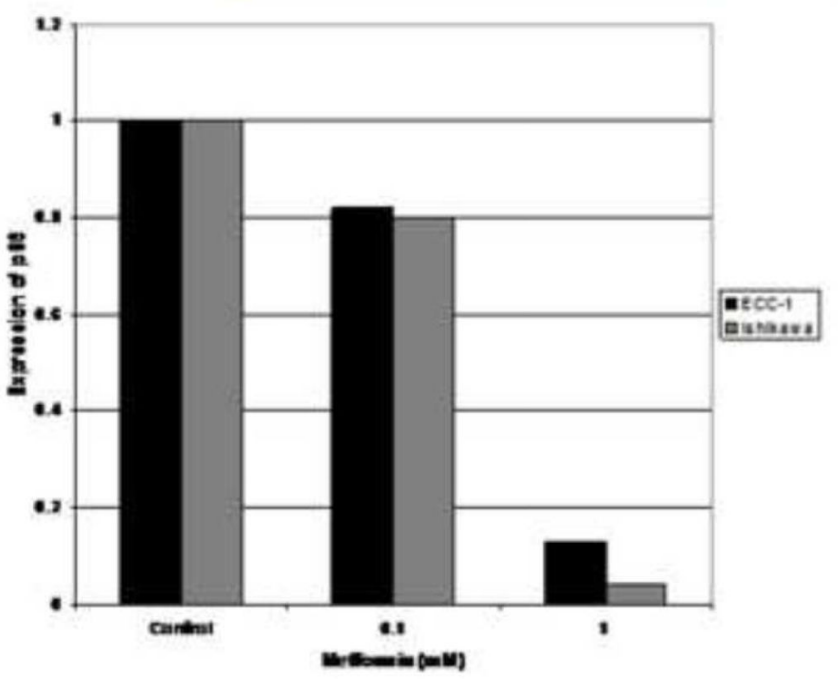

B Paclitaxel (nM)
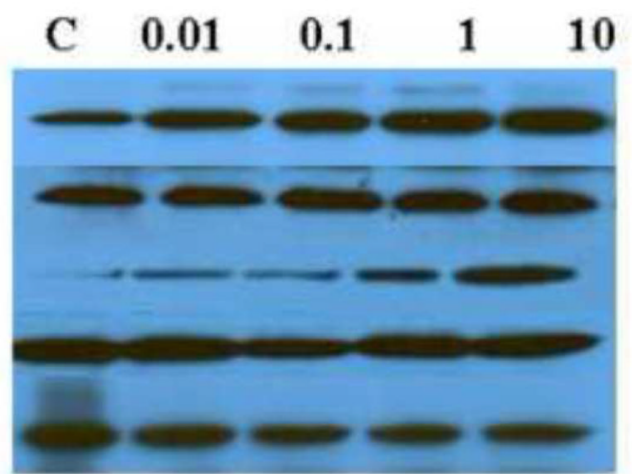

P-S6

Total-S6

P-S6

Total-S6

$\beta$-actin

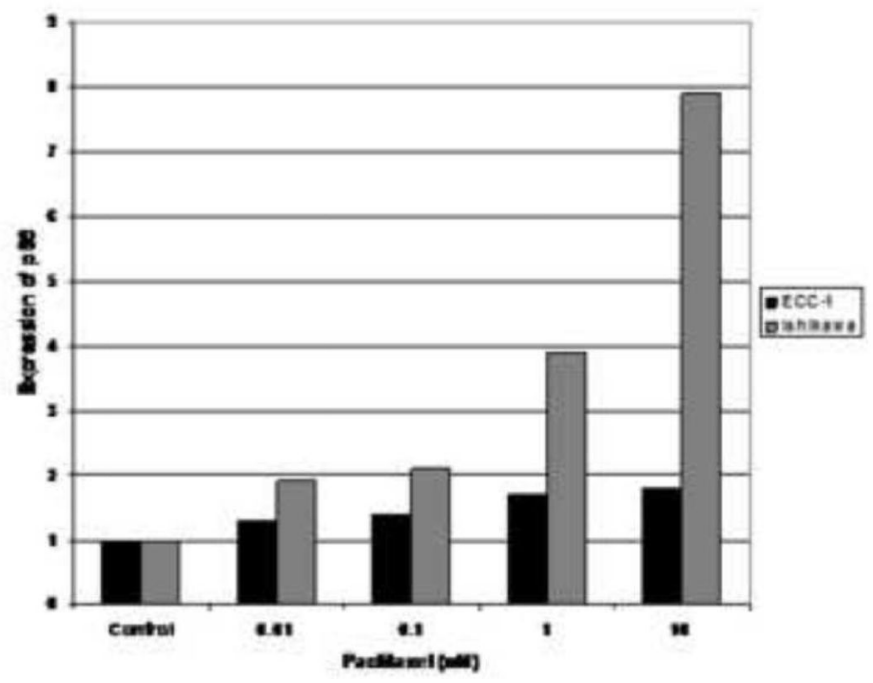


C

Ishikawa

\section{ECC-1}
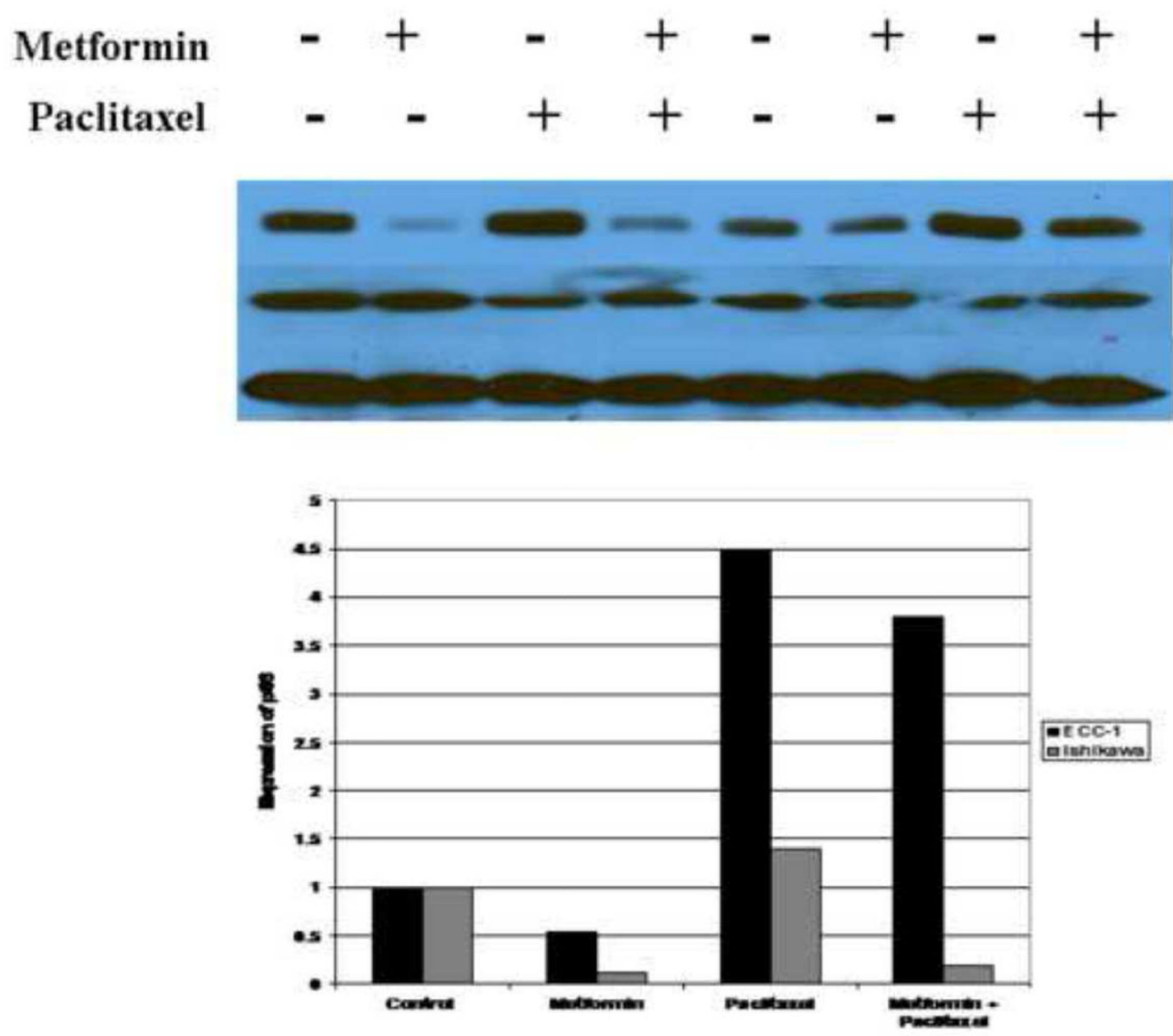

Figure 6. The effects of paclitaxel and metformin on phosphorylation of S6 in the Ishikawa and ECC-1 cell lines

The cells were treated with metfomin (A), paclitaxel (B) or both in combination (C) for 24 hrs. Metformin $(0.1-1 \mathrm{mM})$ decreased phosphorylation of S6 and paclitaxel $(0.01-10$ $\mathrm{mM}$ ) increased phosphorylation of S6 in dose dependent manner as determined by Western immunoblotting. The densitometric analysis of band intensities, as normalized to the $\beta$-actin internal control, is represented under each Western blot and signifies the fold increase or decrease in phosphorylated S6 expression. (P-S6 = phosphorylated S6) 